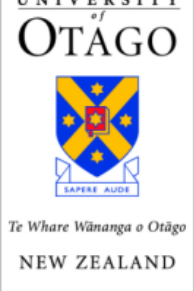

ISSN 1178-2293 (Online)

University of Otago

Economics Discussion Papers

No. 1011

School of Business

Te Kura Pakihi

September 2010

\title{
Expropriation of Foreign Direct Investments: Sectoral Patterns from 1993 to 2006
}

\author{
Chris Hajzler
}

Address for correspondence:

Chris Hajzler

Department of Economics

University of Otago

PO Box 56

Dunedin 9054

NEW ZEALAND

E-mail: chris.hajzler@otago.ac.nz

Telephone: 6434797387

Fax: 6434798174 


\begin{abstract}
This paper documents expropriation of foreign direct investment (FDI) across all developing countries for the 1993-2006 period, extending work by Kobrin $(1980,1984)$ and Minor (1994). This unique data set on worldwide expropriation between 1960 and 2006 is used to highlight several (interrelated) stylized facts. First, although expropriations have become less frequent compared to the 1970s, the number of takings has risen since the mid-1990s. Second, foreign firms are more vulnerable to expropriation in resource-based sectors, particularly in mining and petroleum. Third, the timing of expropriation coincides with fluctuations in mineral output price levels. Finally, when newly constructed FDI stock estimates are used to compare the sectoral distribution of FDI of recent expropriating countries to that of non-expropriating countries, we find that expropriating countries have a higher average share of aggregate FDI located in resources; however, this difference is not reflected in average sector production shares. This last fact is puzzling given that natural resource-based FDI has traditionally been considered high risk.
\end{abstract}

JEL Classification: F23, F43, F51, F59 


\section{Introduction}

Expropriation is a common form of political risk where a host-country government seizes a company's assets without fair compensation, and is a frequently cited barrier to foreign investment in many developing countries. ${ }^{1}$ In an effort to understand the extent of such risk, when governments are likely to expropriate and what they take, a number of studies have documented expropriation of FDI for large samples of developing countries. These data have been instrumental in identifying technological, political, and macroeconomic determinants of expropriation patterns over time and across industrial sectors. These studies have mostly focused on the 1960-1990 period. Relatively little is known about global expropriation patterns in more recent decades.

This paper is a continuation of these earlier efforts, constructing data on international expropriations and FDI, by industry, in all developing countries for the 1993-2006 period. Building on the work of Kobrin (1980, 1984) and Minor (1994), a frequency-based measure of expropriation is examined (rather than value of assets), which has the advantage of allowing for relatively comprehensive country coverage. $^{2}$ Taken together, these data represent the most extensive historical coverage of developing country expropriations from 1960 to $2006 .{ }^{3}$ Examining sector and time patterns over this period, we evaluate a number of earlier predictions and reconsider several hypotheses. A number of the empirical regularities that we document using our expropriation database corroborate findings already emphasized in the literature, and we review explanations for this set of "stylized facts." New evidence relating sectoral patterns of FDI and expropriation in developing countries is also presented, making use of unique country FDI stock data according to major industrial sector.

Specifically, the following empirical patterns are evaluated and discussed. First, expropriation is less likely after 1980 in comparison to the 1960s and early 1970s, both in terms of frequency and the share of the total stocks of developing country FDI affected. However, the number of expropriations has risen since the mid-1990s, with a large proportion occurring in Latin America and Central and Eastern Europe. The virtual disappearance of expropriation during the 1980s is in part attributed to the harmonized confiscation of virtually all vulnerable investments a decade earlier. In addition, developing country commitments to the major multilateral investment treaties in the late 1970s and early 1980s reflect a general willingness of host-country governments to invite new foreign investments. These agreements have also provided a framework for resolving investment disputes with the aid of a formal, international arbitration process, which may help to resolve contract disputes before they result in the state taking extreme actions against the firm. In most instances of expropriation, however, international treaties and arbitration seem

\footnotetext{
${ }^{1}$ For investors in extractive sectors, security of property rights is identified in several surveys as the most important factor next to wealth of mineral deposits in deciding where to invest. See, for instance, Otto (1992) and the IMF Capital Markets Consultative Group (2003).

${ }^{2}$ The unit of measure, an expropriation "act" worldwide, described first in Kobrin (1980), is defined as the expropriation of any number of firms in a given industry and in a a given year. The practical considerations making it the least imperfect measure of expropriation are discussed in Section 2.

${ }^{3}$ Tomz \& Wright (2010) have recently constructed similar data for the 1900-1960 period, although we do not include this earlier period in our main analysis.
} 
incapable of significantly impacting on these decisions. In sum, although expropriations are much less widespread compared to their peak in the 1970s, such risk remains an important consideration for foreign investors deciding where to invest.

Second, FDI in resource-based sectors is more vulnerable to expropriation, particularly in mining and petroleum. Compared to the relative importance of these sectors in aggregate investment and output, foreign investment is expropriated more often in mining and petroleum than in other industries, and this pattern is fairly stable over time. Truitt (1970) is among the first to recognize this pattern, and a variety of explanations for the relatively high risk in extractive industries have been explored. Comparing the sectoral distribution of FDI of recent expropriating countries to that of non-expropriating countries, we present a new (and somewhat puzzling) observation that requires a more nuanced interpretation of sectoral patterns than those already proposed. We find that expropriating countries have a higher average share of aggregate FDI located in resources, and yet this difference is not reflected in average sector production shares. That countries which are more likely to expropriate attract a relatively large proportion of FDI in historically high-risk industries suggests that governments in these countries are offering additional investment incentives in resources (such as cheap mineral rights) to compensate for these risks. We review anecdotal evidence linking expropriation risk to mining sector concessions along these lines.

Finally, we find that high resource output prices increase the likelihood of expropriation. This finding lends support to a standard assumption in the theoretical literature that the value of the assets seized figures prominently in the host country government's decision to expropriate. ${ }^{4}$ Expropriation is at least in some sense driven by opportunism, rather than reflecting mere shifts in political ideology, a point Kobrin (1980) and Jodice (1980) have also stressed.

The rest of this paper is organized as follows. Sections 2 and 3 outline the expropriation and sector FDI data, respectively, providing definitions and descriptions of data collection and measurement. In Section 4, dynamic and sectoral patterns of expropriation are examined, and both old and new accounts of the main facts are discussed. Section 5 concludes with a discussion of the contribution of our findings to both consolidating and reshaping several perspectives on expropriation of foreign investment.

\section{Expropriation Data: 1993-2006}

The dataset documents expropriations of FDI according to the primary (3-digit) industry classification of the affiliate firm. The work of Kobrin $(1980,1984)$ represents the initial phase of this research agenda, documenting expropriations for the 1960-1979 period. This has provided the framework for subsequent updates of the data set by Minor (1994) and this paper. ${ }^{5}$

\footnotetext{
${ }^{4}$ See Eaton \& Gersovitz (1984), Cole \& English (1991), Thomas \& Worrall (1994) and Tomz \& Wright (2010), to list just a few examples that take this approach.

${ }^{5}$ Minor (1994) extends Kobrin's data to include the 1980-1992 period. More recently, Tomz \& Wright (2010) have extended these data backward to cover the period 1900-1960. We document expropriations from 1993 to 2006, including 3 cases during the 1989-1992 period apparently missed by Minor.
} 
Kobrin's (1980) analysis marked a time when a large wave of expropriations of FDI in Africa and South America had just ended and this type of political risk began receiving much attention in the international business and economics literature. His method provides an ideal standard for subsequent empirical work and his notion of expropriation has a number of conceptual and practical advantages. Expropriation is difficult to measure - broadly speaking, expropriation can be viewed as any change in the terms of a contract that results in the forced transfer of part of the value of the investments from the owner to another party (and which is not previously agreed under the contract). The extent to which any country's government expropriates is therefore a matter of degree.

It has been common in empirical analysis of expropriation to focus on the transfer of ownership of property or assets. An obvious measure of the extent of expropriation is the total value of expropriated assets (less compensation). However, such data are often very difficult (or impossible) to obtain. ${ }^{6}$ It is therefore necessary to rely on a measure of expropriation based on the frequency of reported cases for most comparisons. Kobrin (1980) formulates a measure intended to address the potential difficulties that can arise when expropriations are counted at the level of the firm. Historically, many expropriations involve the nationalization of entire industries (when considered at the three-digit SIC level), yet some industries are often occupied by just a few large-scale operations. In such cases, simply counting the number of firms that have had assets expropriated could, for instance, result in placing a much greater weight on the confiscation of dozens of small farms or estates compared to the expropriation of one large mining operation. Comparing the severity of expropriation across both industries and countries using a firm-level count measure might therefore not be very informative in certain cases. ${ }^{7}$

To minimize these potential distortions when comparing expropriation intensities, Kobrin defines the expropriation "act" as the involuntary divestment of assets of any number of direct investment firms, within a given three-digit industry and in a given year. ${ }^{8}$ The data also distinguish between 'mass' and 'selective' expropriations, and between four types of takings. ${ }^{9}$ These types are (i) explicit confiscations of property, (ii) breaches of contract (such as forced renegotiation of the contract terms) under which it is no longer profitable for the firm to continue operations, (iii) extra-legal interventions or transfers of ownership effected by private agents and not resolved by government, and (iv) the forced sale of property. The common thread in each of these categories is that at least some part of the direct investor's ownership

\footnotetext{
${ }^{6}$ Increasingly, with the rise in claims made through international investment treaties such as the Multilateral Investment Guarantee Agency (MIGA) and the World Bank's International Centre for Settlement of Investment Disputes (ICSID), the total value of assets affected are reported by the company. However, these data are only available for recent years and for member countries. We examine a combination of arbitration claim figures and estimated asset values from independent media sources as a robustness check for several of our comparisons, but these ignore any compensation. Taking into account compensation is difficult because (i) such settlements may take many years to materialize, and actual payments may be delayed further still, and (ii) compensation often goes unreported, particularly when arbitration claims are settled privately.

${ }^{7}$ This issue is discussed in detail in Kobrin $(1980,1984)$.

${ }^{8}$ This measure distorts comparisons in the other direction whenever a single, small-scale enterprize or property is expropriated. However, these events are much less common in Kobrin's data.

${ }^{9}$ Mass expropriations are identified as broad nationalizations of foreign property across many industries and displaying evidence of some ideological (typically leftist or socialist) objectives. However, none of the cases documented since Angola, Ethiopia, and the Republic of Tanzania in the late 1970s are of this type.
} 
rights are involuntarily relinquished without fair compensation.

It is important to note that Kobrin's measure emphasizes transfer of ownership and does not include cases typically referred to as 'creeping expropriation'. This less overt action takes the form of sudden discriminatory or confiscatory taxes on property, fines, currency devaluations, limitations on profits, or withdrawal of licences and permits, and these incidents are not counted where no transfer of ownership title is involved. However, there is a clear conceptual overlap between direct and indirect forms of expropriation. A sudden 100 percent tax on a company's asset returns, for instance, may be more confiscatory than an outright nationalization of property that allows some degree of compensation. Nonetheless, a line must be drawn in order to arrive at a practical definition of expropriation, and the line chosen is likely to be reported with the most consistency in the primary sources used. ${ }^{10}$ Focusing on cases involving the transfer of property makes reasonable the goal of arriving at a (close to) exhaustive database of developing country expropriations by systematically scanning a broad range of primary sources. In addition, this measure provides a means for comparing the relative degree or intensity of expropriation when reliable data on the value of assets involved are not available.

Data are assembled by searching a large number of primary sources, many of which correspond to the periodicals used by Kobrin in constructing his original data set. ${ }^{11}$ Each reported expropriation case is checked against the criteria for an act. (Often this involves (i) verifying that partial or full divestment of the investor assets occurred, including cases where the company has terminated operations in the host-country, and (ii) that the investment counts as FDI according to the $10 \%$ ownership criteria.)

The complete data set consists of the 560 acts recorded in Kobrin (1984) during the 1960-1979 period, 16 acts during 1980-1986 documented by Minor (1994), and the update of this paper, which contains 49 additional expropriation acts in 24 countries. These countries includes seven "transition" economies of the former Soviet bloc (including one case involving Russia itself). The remaining 17 expropriators during this period are all "repeat offenders" from the previous three decades. Table 1 lists the 49 expropriation acts documented over the 1989-2006 period, according to country and major (2-digit ISIC) industry.

A majority of these cases involve outright confiscation of the firm or a share of firm assets. In some instances, however, the host-country government has attempted to increase its share of the project returns with an increase in taxation or other contract change that is so severe that the company has determined that it is better off shutting down than accommodating the new terms. A recent case is Bolivia's 2006 nationalization of its oil and gas sector. Under the new policy, foreign companies were given 180 days to either renegotiate their contracts, which would transfer $82 \%$ of the value of production to the state, or to shut down. In May of the previous year, oil producer contracts had already been revised to transfer $50 \%$ of production to the state. The government's public justification for the nationalization is to end the

\footnotetext{
${ }^{10}$ More extreme cases of sudden changes in the terms of a contract, such as increases in tax rates, will result in a transfer of ownership if the company decides it is no longer worthwhile to operate and is unable to liquidate all of its assets. These cases will be recorded as expropriations in our database and are discussed in more detail below.

${ }^{11}$ Details are provided in the Data Appendix.
} 
Table 1: Expropriating Countries: 1989-2006

\begin{tabular}{lll}
\hline Country & Years & Sectors \\
\hline \hline Antigua \& Barbuda & 2002 & Svc \\
Argentina & 2001 & Svc \\
Azerbaijan & $2005,2006,2006$ & Pet, Mfg, Util \\
Bolivia & $2000,2005,2006$ & Util, Pet \\
Congo (Dem. Rep.) & $1993,1997,1998,1999$ & Mfg, Svc, Min \\
Cote d'Ivoire & 2003 & Svc \\
Dominican Republic & 1994 & Util \\
Ecuador & 2006 & Pet \\
Egypt & $1989,1991,1995$ & Svc \\
Georgia & 1996 & Svc \\
Indonesia & 1998,1998 & Util \\
Kazakhstan & $1992,1999,2002$ & Pet, Util, Min, Svc \\
Kenya & 1998 & Const \\
Kyrgyzkstan & 2004 & Min \\
Lesotho & 1992 & Min \\
Mexico & $1995,1998,2001$ & Mfg, Svc \\
Russia & 2006 & Pet \\
Serbia & 1999 & Mfg \\
Sri Lanka & 1990 & Mfg \\
Turkmenistan & 1998 & Pet \\
Uzbekistan & 2006 & Min \\
Venezuela & $2001,2002,2005,2006$ & Agr, Mfg, Min, Pet, Svc \\
Yemen & 2005 & Pet \\
Zimbabwe & 2004,2005 & Agr \\
\hline
\end{tabular}

Sector Abbreviations: Agriculture (Agr), Construction (Const), Manufacturing (Mfg), Mining (Min), Petroleum (Pet), Services (Svc), and Utilities (Util).

"abusive profits" accruing to foreign multinationals. ${ }^{12}$ President Morales had even declared that "There is no confiscation nor expropriation of company property. Their installations will continue to be their installations. This nationalisation is of natural resources."13 Share prices of all foreign firms affected had sharply fallen in response to the anticipated loss in future revenues. However, only two firms chose to shut down during 2006, and it is these firms that are counted towards a single expropriation act.

It is also worthwhile to note that several outright nationalizations in the sample involved some form of compensation, sometimes in accord with the laws of the state or policy of the expropriating government, but more often at the behest of an international dispute settlement panel. It is sometimes difficult to identify an involuntary and inadequately compensated transfer of ownership. Nationalizations and forced

\footnotetext{
${ }^{12}$ See Edna Fernandez, "Pressure mounts on Bolivian leader after energy seizure”, Times Online, May 3, 2006. (Retrieved at www.timesonline.co.uk.)

${ }^{13}$ According to The Wall Street Journal (Eastern Edition, May 2, 2006: p.1), these producers also represented Bolivia's two largest oil fields.
} 
sales can involve at least partial compensation for divested assets, yet to the extent that these divestments are forced upon firms, it is not unreasonable to think that compensation falls short of the assets' market values. In April 2008, for instance, the Venezuelan government entered into negotiations for takeover of the country's largest steel producer, threatening to expropriate the company outright if the company continued to demand too much in terms of compensation. By May 2009, negotiations terminated with an agreement to pay US $\$ 1.97$ Billion for the company, approximately half of what the parent company had sought. Given the circumstances under which the takeover is negotiated, it is reasonable to suspect that final compensation was below fair market value. ${ }^{14}$ The threat of outright confiscation is credible according to Venezuela's recent expropriation record, and if a large share of the capital invested is difficult or impossible to liquidate, the company may have no choice but to accept a low price from the state. Moreover, even when compensation is promised or awarded, it is unclear if and when the state will ultimately fulfill its end of the bargain. ${ }^{15}$ On the other hand, a company under threat of nationalization potentially sees a captive buyer, and may indeed demand unfair compensation. A parallel argument can be made for cases where the government forces investors to sell part or all of their equity to domestic buyers. A challenge in identifying cases of expropriation is to distinguish cases where divestment of assets is genuinely opposed by the owner from the general bargaining posture of the firm (Kobrin, 1980).

Mexico provides an example of a borderline case. In September 2001, the Mexican government nationalized 27 of the country's 60 sugar mills with the official aim of revitalizing the industry. Many mills were saddled with large debts, and several closed down as a result of increased competition within the U.S. sugar market (the main export market). ${ }^{16}$ The government had expressed its intention to compensate investors for expropriated property and to privatize these mills following renovations and restructuring. Only a few of these expropriations seem to have been seriously contested, and they might not have been counted if it were possible to assess whether all investors had received fair compensation. The litigation claims that have ensued cast some doubt on this claim, and at least two of these claims against the Mexican government have already been decided in favour of the investors. ${ }^{17}$

We examine patterns of expropriation and foreign investment over time and according to industry in Sections 4.1 and 4.2. We first provide a brief overview of the sector FDI data used.

\section{Sector FDI Stock Data: 1970-2003}

In order to examine relationships between expropriation and investment patterns, we construct perpetualinventory sector FDI stocks for a sample of 42 developing countries (and 65 countries in total) from FDI

\footnotetext{
${ }^{14}$ According to the April 28, 2008 issue of the Wall Street Journal (Online), the parent company Ternium requested $\$ 4$ Billion for its 60 percent stake. President Hugo Chavez claimed "I am not going to pay $\$ 4$ Billion for that company. ... If they don't want to reach an agreement with us, I'll sign an expropriation decree."

${ }^{15}$ According to Bloomberg's May 7, 2009 online article, "Venezuela, Ternium Agree on \$1.97 Billion for Sidor", Venezuela had still owed approximately $\$ 10$ billion for unpaid nationalizations since 2006 .

${ }^{16}$ See Financial Times, 17 September 2001, and Reuters, 3 September 2001.

${ }^{17}$ These arbitration claims belonged to GAM Mills in 2004 and Machado Mills 2006.
} 
inflow data (or imputed FDI flows from historical cost stock estimates) published in a variety of sources. These series span the 1970-2003 period, ${ }^{18}$ and correspond to the three major industrial sectors: Primaries, Manufacturing, and Services.

Sector level data on inward stocks reported in official national statistics, as well secondary sources, are typically 'book values' (aggregate stocks derived from survey-based records of assets on the foreign affiliates' books). When book value estimates are not available, stocks are usually estimated by simply cumulating current dollar FDI inflows, which are in turn frequently derived from central bank records of foreign exchange transactions between the direct investor and affiliated company and supplemented with survey data on reinvested earnings. ${ }^{1920}$

A well-known problem with these measures of total assets is their lack of a clear economic interpretation. Both measures are based on aggregating current dollar flow values over time. In particular, it can be difficult to make meaningful comparisons across countries and across time periods in situations of high inflation and volatile exchange rates. ${ }^{21}$

To get around this issue, we construct constant cost estimates of FDI stocks using a perpetual inventory method by converting sector flow data into constant dollars (US and International PPP dollars) before adding them up, net of depreciation. We leave most of the details to the Data Appendix. Ideally, arriving at stock estimates that are comparable across countries and time would involve deflating each flow series by a domestic investment goods price index. Since this statistic can be found for only a small sample of countries, each series is instead converted to US (or PPP) dollars and deflated by the US GDP deflator. The implicit assumption here is that changes in average investment goods prices follow changes in average prices for the economy as a whole, and that these movements are adequately captured by US exchange rate and average price movements. This approach also requires an estimate of depreciation in each sector, which we estimate from sector data on capital depreciation in the Canadian economy.

This exercise is similar to that carried out by Lane \& Milesi-Ferretti $(2001,2007)$ in their construction of country net foreign asset positions. The FDI stocks we estimate differ from their aggregate stock estimates primarily in that they can be interpreted as a measure of the physical units of capital invested rather than the current market value of such investments. Lane and Milesi-Ferretti's estimates, by contrast, allow for capital gains and losses arising from exchange rate fluctuations.

\footnotetext{
${ }^{18}$ The year 1970 indicates the earliest year for which initial FDI stock data is reported for most countries. However, for several countries the earliest period for which stocks could be estimated is 1980, and even later in some cases. Sector FDI flow data used to estimate investment stocks is not available after 2003 in most of the primary sources used.

${ }^{19}$ Secondary sources for FDI stock data constructed in this way include the United Nations Conference on Trade and Development's (UNCTAD) 'FDI country profiles', which can be found at www.unctad.org, the United Nations' World Investment Directory (WID), and various OECD publications (such as Source OECD).

${ }^{20}$ Initial stock assumptions vary by country. Sometimes book values are available from infrequent government or central bank surveys or from early secondary source estimates such as those in Dunning \& Cantwell (1987). If no reliable initial stock estimates are found, they are often estimated by cumulating the earliest recorded inflows over a certain period, the length of which varies according to the hypothesized prevalence of direct investment during earlier years.

${ }^{21}$ To the extent that periodic valuation adjustments to book values take into account goodwill, inflation and economic depreciation, these will be most closely related to market value. However, the market value of FDI in the economy cannot be measured directly due to the large proportion of wholly-owned subsidiary firms and other affiliates composed of non-publicly traded shares.
} 


\section{Analysis of Country Trends}

\subsection{Expropriation Over Time}

Table 2 reports the sectoral distribution of expropriation acts as well as the total number of acts for each decade (bottom row) since the 1960s. Looking across time we see that expropriations are much less frequent since Kobrin's original 1960-1979 study. However, the frequency of acts has risen over since the mid-1990s. Figure 1 shows the peak of expropriations occuring between 1970 and 1975, declining sharply afterwards until the mid 1980s. During the decade between 1985 and 1996, only ten acts are documented. During the 1996-2006 period, by contrast, a total of 41 acts are documented. (15 occurred during the 1996-2000 period and 26 acts occurred during the 2001-2006 period.) The rising number of acts during early 2000s also reflects an increase in the number of countries expropriating. While 14 countries expropriated during the 1980s and 13 countries during the 1990s, 14 countries expropriated in the six years up to 2006 alone.

Table 2: Sector and Time Patterns of Expropriation Acts: 1960-2006

\begin{tabular}{lrrrrr}
\hline & $1960-69$ & $1970-79$ & $1980-89$ & $1990-99$ & $2000-06$ \\
& & & & & \\
\hline \hline Primaries & $\mathbf{3 6 . 8}$ & $\mathbf{4 0 . 4}$ & $\mathbf{5 2 . 9}$ & $\mathbf{3 1 . 8}$ & $\mathbf{4 8 . 1}$ \\
Agriculture & 8.8 & 8.7 & 35.3 & 0.0 & 11.1 \\
Mining & 11.8 & 12.3 & 0.0 & 22.7 & 18.5 \\
Petroleum & 16.2 & 19.4 & 17.6 & 9.1 & 18.5 \\
& & & & & \\
Manufacturing & $\mathbf{2 5 . 7}$ & $\mathbf{2 7 . 4}$ & $\mathbf{2 3 . 5}$ & $\mathbf{1 3 . 6}$ & $\mathbf{1 4 . 8}$ \\
& & & & & \\
Services & $\mathbf{3 7 . 5}$ & $\mathbf{3 1 . 4}$ & $\mathbf{2 3 . 5}$ & $\mathbf{5 4 . 5}$ & $\mathbf{3 7 . 0}$ \\
$\quad$ Banking and Insurance & 12.5 & 11.6 & 0.0 & 0.0 & 0.0 \\
Communication & 1.5 & 2.4 & 0.0 & 0.0 & 7.4 \\
Construction & 0.0 & 1.9 & 0.0 & 9.1 & 0.0 \\
Trade & 7.4 & 4.0 & 5.9 & 4.5 & 3.7 \\
Transportation & 5.9 & 3.3 & 5.9 & 4.5 & 3.7 \\
$\quad$ Utilities & 10.3 & 4.5 & 0.0 & 18.2 & 11.1 \\
Other Services & 0.0 & 3.8 & 11.8 & 18.2 & 11.1 \\
Unallocated & $\mathbf{0 . 0}$ & $\mathbf{0 . 7}$ & $\mathbf{0 . 0}$ & $\mathbf{0 . 0}$ & $\mathbf{0 . 0}$ \\
& & & & & \\
Total & $\mathbf{1 0 0 . 0}$ & $\mathbf{1 0 0 . 0}$ & $\mathbf{1 0 0 . 0}$ & $\mathbf{1 0 0 . 0}$ & $\mathbf{1 0 0 . 0}$ \\
Number of Acts & 136 & 423 & 17 & 22 & 27 \\
& & & & & \\
\hline
\end{tabular}

${ }^{a}$ Values in each column are the percentage of total acts during the time period represented by the industry indicated. The bottom row indicates the total number of acts for each time period. 


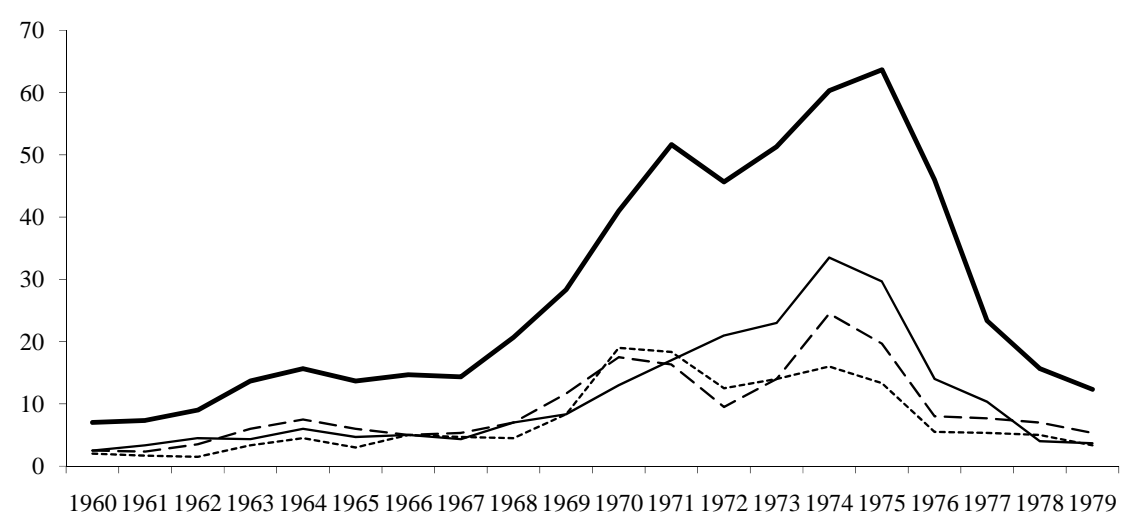

— Primaries ------- Manufacturing --- Services $\longrightarrow$ Total

(a) 1960-1979

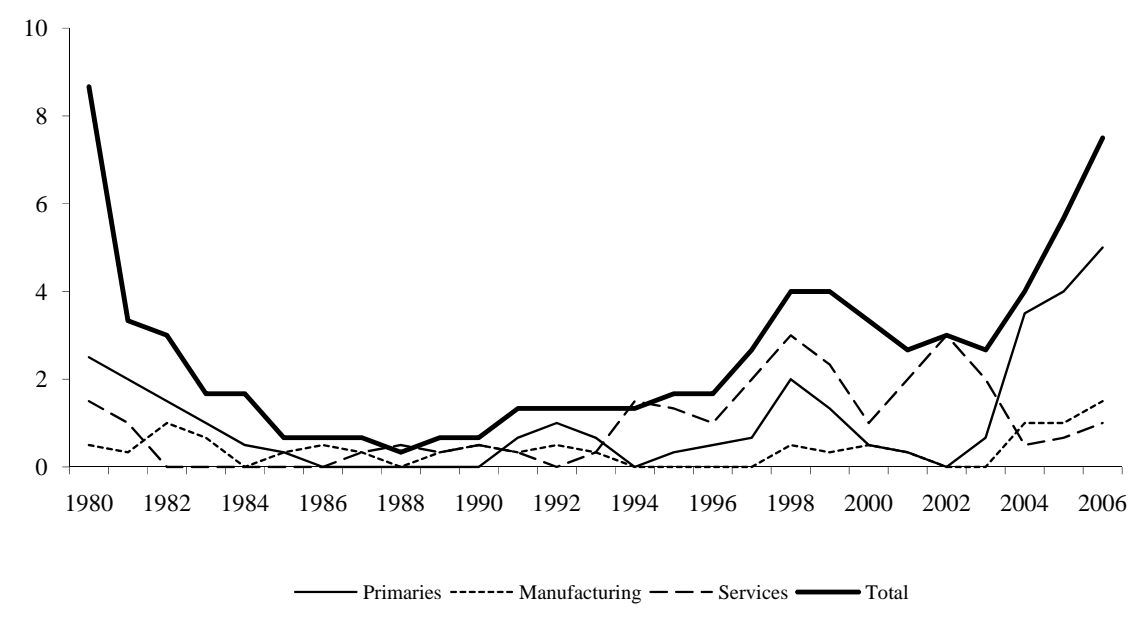

(b) 1980-2006

Figure 1: Expropriation Acts by Sector 
The the increase in expropriation since the mid-1990s can be partly explained by the increasing importance of FDI in many developing countries at around this time. Figure 2 shows world and developing country averages for FDI stocks as shares of value added in each sector. The first panel shows FDI trends in all countries for which data are available, while the second panel shows trends for developing countries only. ${ }^{22}$ Both panels show a substantial rise in the importance of FDI in all all sectors since 1980. As a percent of its 1980 level, the increase in average services FDI as a share of output has been the most dramatic. For developing countries, the increase in primaries and manufacturing FDI show similar trends. By the end of the period, developing country manufacturing FDI stocks represent, on average, almost $45 \%$ of the value of output in this sector. This represents a decline from almost 50\% in 1999. Primaries FDI stocks in sector output rises to similar levels by the end of the period, but the decline since 1999 is somewhat more pronounced.

Relative to stocks of FDI in developing countries, expropriation over the entire 1990-2006 period is less prevalent in comparison to earlier decades. Between 1956 and 1972, for instance, Williams (1975) estimates that 40 countries expropriated $19 \%$ of foreign-owned capital in all LDCs in 1972. Because this estimate is based on a comparison of arbitration claims (compiled from Klessings Archives and the US Department of State), this value should be viewed as an upper bound. Another limitation with this estimate is that it is based on 1972 stocks and it ignores any capital outflow that may have occurred during this period. Kobrin (1980) estimates the value of investments expropriated by 79 countries over the 1960-1976 period, which excludes the large Cuban nationalizations of the 1950s that are included in Williams' estimate, to be $4.4 \%$ of FDI in all developing countries in $1972 .^{23}$

To contrast these estimates with the more recent 1990-2006 period, we also estimate the value of expropriated assets since 1990 using available data on arbitration claims. This value is slightly over US $\$ 20$ Billion, which represents only $1.6 \%$ of the estimated $\$ 1.2$ Trillion stock of FDI in all developing countries in the year $2000 .^{24}$ It is nevertheless interesting to note that the largest recipients of FDI during this period (Brazil, China, and Mexico) account for $43 \%$ of the stock of FDI in developing countries in 2000. When we excluding these three countries, the proportion of expropriated assets is $3 \%$, which is closer to, but still less than, Kobrin's figure for the 1960-1979 period. $^{25}$

In light of the recent rise in expropriation activity, however, an important question is whether one can expect a resurgence in expropriations to the extent observed during the 1960s and 1970s. The consensus

\footnotetext{
${ }^{22}$ The series have been truncated at 1980 owing to the lack of data for many countries for earlier years.

${ }^{23}$ This estimate is based on the percentage of foreign-owned firms affected by expropriation, and on the total number of direct investment firms in all developing countries, which is imputed from information on the number of U.S. direct investment firms operating abroad and an estimated share of U.S. investment in the stock of FDI in all developing countries. See footnote 28 in Kobrin (1980) for details.

${ }^{24}$ Table 3 in the next section shows the sectoral distribution of claims according to major industry. Aggregate country FDI stocks are from Lane \& Milesi-Ferretti (2007).

${ }^{25}$ It might appear that the proportion of foreign assets actually expropriated is rather small, and as a result the economic significance of expropriation risk on foreign investment in all developing countries is also expected to be small. However, our measure of expropriation used is quite narrow and ignores cases that do not involve transfer of ownership. Unfortunately we are unable to verify the extent to which the patterns observed for expropriation acts coincide with broader expropriation behavior such as bribes and contract repudiation.
} 


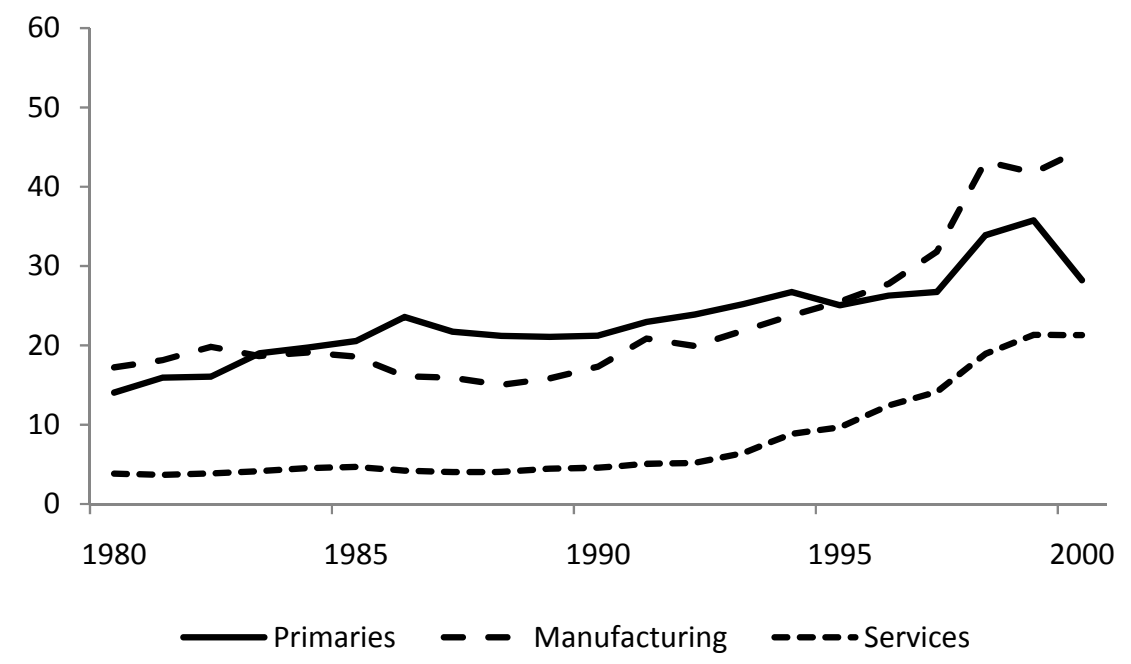

(a) World Average

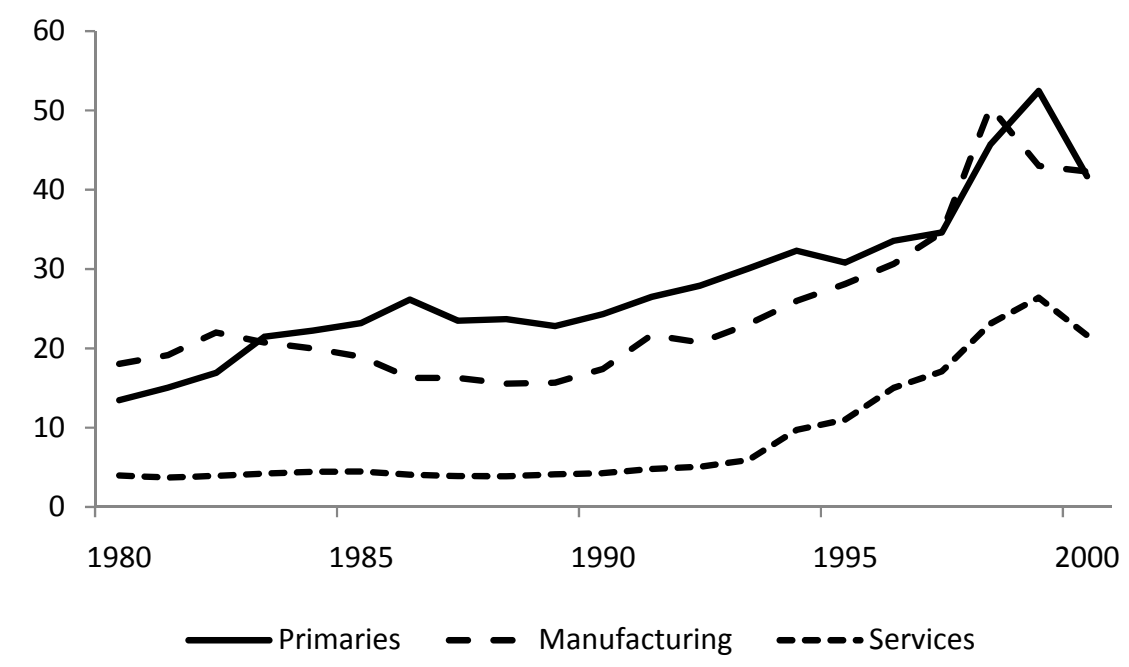

(b) Developing Country Average

Figure 2: Sector FDI Stocks: Percent Value Added 
in much of the literature is that this is unlikely. A variety of explanations have been put forth. First, the extent of the rise in expropriation acts during the 1960s is rather unique in that the 1950-1970 period marked the beginning of colonial independence for many countries in African and East Asia. Countries achieving independence since 1960 account for almost half of all acts between 1960 and 1980. Kobrin (1984) suggests that, although independence and sovereignty are necessary conditions for expropriation, the motivation was partially symbolic. Pressures to politically assert independence, combined with a general perception that lack of indigenous ownership and managerial control was to blame for economic development achievements failing short of post-independence expectations, meant that many governments were reluctant to negotiate with foreign firms for improved contract terms. It is hypothesized that both the political pressures to assert independence and the view that foreign ownership is responsible for poor economic outcomes are unlikely to resurface as dominant political factors in most countries. ${ }^{26}$

Kobrin (1984) also argues that increased local managerial and regulatory expertise has meant that many developing countries now have a greater capacity to control the behavior of multinational firms (as well as exert greater influence over the host-country share of the returns) through legal and contractual means, reducing the need for confiscatory measures. Gillis (1982), Mikesell (1984) and Duncan (2005) argue that post-1980 mining and petroleum contracts have generally allowed for greater profit-sharing. The primary advantage of traditional royalty-based tax systems is that they ensure an up-front and relatively stable revenue stream as soon as production starts. A drawback is that investors require high returns in high-price states in order to compensate for losses when commodity prices are depressed. In addition, many countries will require rental fees as well as upfront discovery and production bonuses, which must be balanced by higher investor shares of the returns during the production phase (Baunsgaard, 2001). Since the 1970s, developing country governments have experimented with production and equity sharing contracts, as well as resource rent or excess return taxes. These alternative contracts serve to raise the tax burden in the same (or greater) ratio as company profits. Under a production sharing contract, profit is calculated on the basis of deductions for production costs and is shared between the investor and government. Equity sharing implies a similar distribution of returns between the government and investors. Resource rent and excess profit taxes aim to cap the investor's rate of return, but will usually imply that government revenues remain low (or even zero) until a certain threshold return on the project is reached. Compared to the royalty-based contract, these alternative arrangements potentially lower the incentive to expropriate when the value of the mineral is high by decreasing the wedge between the value of assets and government take.

Minor (1994) additionally suggests that the commitment of many developing countries to the principles of international investment treaties such as the Multilateral Investment Guarantee Agency (MIGA) and the Overseas Private Investment Corporation (OPIC) also reflects a shift in general host-country attitudes towards foreign investment. OPIC encourages or discourages foreign investment in member

\footnotetext{
${ }^{26}$ The former is assumed to be the result of a growing sense of national identity and sovereignty over time, giving way to a more pragmatic view towards foreign investment. The latter is attributed to a retrospective observance of the relatively poor performance of state-run enterprizes following expropriation episodes in many countries.
} 
countries by offering (or not offering) financing and political risk insurance to investors. MIGA offers similar financing and insurance incentives to investors, but additionally requires that member states contribute a membership fee which, in the event a conflict arises between the state and foreign investor, MIGA may claim against any compensation or insurance awarded to the investor. Many countries have also joined the International Center for Settlement of Investment Disputes (ICSID), in which member states commit to resolving conflicts with investors through an impartial arbitration panel.

These developments in since the 1970s suggest that expropriation is unlikely to reach the historic levels of this decade, and that the large foreign investment inflows in developing countries since the mid-1990s is subject to (and perhaps also a result of) lower political risk. However, there are several reasons not to be overly optimistic concerning the impact of innovations in resource-sector contracts and the increased country membership in international investment treaties.

The degree of profit sharing in typical petroleum sector contracts has certainly increased in many developing countries since 1970, but the use of alternate tax instruments in other extractive industries has not been widespread. Recent studies by Baunsgaard (2001) and Otto et al. (2006) compare mining and petroleum sector taxes for broad selections of developing countries. ${ }^{27}$ The evidence from these studies is that most countries still use standard royalties in mining ( $75 \%$ of countries considered) and in petroleum (80\%). Although production sharing arrangements are used in the petroleum sector in just over half of the countries considered, they are still uncommon in mining. ${ }^{28}$ Resource rent taxes are also rarely used in developing country mining and petroleum sectors. As Baunsgaard (2001) points out, they are unattractive to many governments because the revenue stream becomes back-loaded and uncertain, and deriving the appropriate thresholds is not an easy task. Of the countries surveyed, only $25 \%$ rely exclusively on royalties and income taxes in the petroleum sector, but this figure is $60 \%$ for mining.

In countries and industries where these alternative tax instruments have been adopted, their quantitative impact on expropriation risk is uncertain. More detailed data indicating how their relative importance as sources of revenue in several countries has evolved since the 1970s would allow one to estimate such a relationship. We believe this is an interesting question for future research. It is important to note, however, that a country's mining tax structure may be endogenous and a low or zero royalty does not necessarily imply lower risk for foreign investors. Evidence that the royalty rate is used for attracting resource-based investments when political risk is high is considered in the next section.

Although organizations such as OPIC, MIGA and ICSID encourage FDI in developing countries by reducing informational costs and facilitating dispute settlement, a country's membership and adherence to their guidelines are voluntary. (Almost all countries that have expropriated since 1990 were members of MIGA at the time of the taking.) A formal dispute settlement process provides a measure of impartiality in resolving disagreements, which can be effective in reducing tensions and reducing the need for extreme

\footnotetext{
${ }^{27}$ There is considerable overlap in country coverage between these studies. Together, information on the royalty and tax systems, including specific rates, are available for the mining sectors in 30 countries and for petroleum in 63 countries.

${ }^{28}$ Equity sharing is not common in either mining and petroleum. This may be due to a perceived conflict of interest arising when the government is both a regulator and direct stake-holder in these projects.
} 
actions. When the benefit of expropriation is determined on the basis of the value of assets taken, however, it is unlikely that membership will significantly influence the decision to expropriate. The direct penalties that MIGA can impose on non-compliant countries are often much less than the value of assets to be gained, and reputational costs are likely a greater concern to the expropriating government. To give a few examples, Bolivia's MIGA subscription is less valued less than US \$2 Million, while the country's 2006 Petroleum expropriations involve an estimated US \$4 Billion in investor claims. Similarly, claims for the expropriation of Occidental Petroleum in Ecuador in 2006 are over \$1 Billion compared to MIGA subscription fees of less than US \$3 Million. ${ }^{29}$ Moreover, Boliva and Ecuador have since decided to simply terminate their ICSID membership rather than pay the compensation claims brought against the state. With the rise in the price of oil and gas and the increased nationalistic politic in South America, neither investment treaties nor arbitration clauses are preventing host nations from reconsidering their current mineral agreements. ${ }^{30}$

Developments in the international regulatory environment, as well as the adoption of mining sector contracts that provide a greater degree of profit sharing in many developing countries, will have certainly contributed to the reduced hazard of expropriation since the 1970s. Yet it seems unlikely they are the primary cause of lower global risk. The near complete collapse of expropriation acts during the late 1980s and early 1990s appears to be associated with other factors, including the fact that nationalization of politically sensitive industries was largely complete by the end of the 1970s. The subsequent wave of privatization and FDI will have contributed to the rise in expropriation cases since the mid-1990s. Commodity prices also seem to have played a role in the time pattern of expropriations, a factor that is considered in detail in the next section.

\subsection{Sectoral Patterns}

A sectoral breakdown of expropriations indicates that certain industries, notably extractive industries such as mining and petroleum, have been particularly popular targets of expropriation since 1960. Table 2 shows that roughly $40 \%$ of all acts during the 1960-2006 period occurred in resource-based industries. This share significantly larger than the average primaries value added and FDI shares in developing countries, which are approximately $23 \%$ for this period. Most of these acts occur in mining and petroleum. Manufacturing, by contrast, is under-represented in terms of percentage of total acts. In services, the share of takings roughly corresponds to sector output shares during the 1990s. Within this sector, however, Utilities are frequently expropriated. Banking and Insurance has also been a relatively frequent target during the 1960s and 1970s, but no takings are recorded after 1980. We also note that, despite large fluctuations in the proportion of takings for selected industries, the sector distributions appear to be fairly stable overall over the longer time horizon, apart from a decline in the manufacturing share and a

\footnotetext{
${ }^{29}$ Details on country membership shares are found in Schedule A of the Convention Establishing the Multilateral Investment Guarantee Agency, available at at www.miga.org.

${ }^{30}$ This view is expressed in a letter to the editor by Ecuadorian Ambassador to the United Kingdom Teodoro Maldonado, published in The Economist, 24 June 2006, at page 16.
} 
Table 3: Sector Distribution of Expropriation Acts and Value in 1990-2006 (percent shares)

\begin{tabular}{lrrr}
\hline 1990-2006 period & Acts & Firms $^{\mathrm{a}}$ & Value $^{\mathrm{b}}$ \\
\hline \hline Primaries & 40.8 & 47.1 & 58.3 \\
Agriculture & 6.1 & 7.4 & 0.4 \\
Mining & 20.4 & 17.6 & 16.2 \\
Petroleum & 14.3 & 22.1 & 41.6 \\
& & & \\
Manufacturing & 14.3 & 17.6 & 9.4 \\
& & & \\
Services & 44.9 & 35.3 & 32.3 \\
$\quad$ Banking and Insurance & 0.0 & 0.0 & 0.0 \\
Communication & 4.1 & 2.9 & 7.6 \\
Construction & 4.1 & 2.9 & 3.5 \\
$\quad$ Trade & 4.1 & 2.9 & 0.8 \\
$\quad$ Transportation & 4.1 & 2.9 & 2.0 \\
$\quad$ Utilities & 14.3 & 10.3 & 13.4 \\
$\quad$ Other Services & 14.3 & 13.2 & 4.9 \\
Unallocated & 0.0 & 0.0 & 0.0 \\
$\quad$ Total & & & \\
\hline
\end{tabular}

${ }^{a}$ Excludes the 50 Dutch-owned farms estimated to have been expropriated in Zimbabwe in 2005.

b Excludes Bolivia's Petrobas and Russia's Shakalin petroleum projects.

rise in the services share.

One concern might be that the unit of measurement, an "act", does not adequately capture the degree to which these sectors are targets of expropriation. As already discussed, potential differences in the number and value of firms taken during each act across sectors could make sectoral or cross-country distributions sensitive to the expropriation measure adopted. Table 3 examines the sectoral distributions of takings according to two alternative measures of expropriation: the number of firms affected and the total value of company assets claimed over the 1990-2006 period. We see similarly large shares of primaries sector expropriations. ${ }^{31}$

This tendency to expropriate in the petroleum and mining industries has been emphasized in a number of previous studies (Kobrin, 1980; Jodice, 1980; Kennedy Jr., 1993). Rood (1976) also emphasizes

\footnotetext{
${ }^{31}$ The value of assets is taken to be the divested share of cumulative investments made by the direct investors in the project, whenever reports on such investments are available. Where these specific investment data are not found, but an international arbitration claim has been filed, the value of the final award (or the award claimed if the case has not been concluded) is used instead. This excludes Bolivia's Petrobas and Repsol as well as Russia's Shakalin petroleum projects, which together account for more than half the estimated value of all expropriated investments. In calculating the shares of total firms affected, the 50 or so Dutch farms expropriated in Zimbabwe during 2005 are excluded. When this figure is included, agriculture accounts for over $50 \%$ of firms affected, and primaries $70 \%$.
} 
the disproportionate amount of resource sector takings, noting that during the 1970s nationalization of Petroleum in Nigeria, scores of foreign-owned construction and manufacturing corporations were left largely untouched. (The Banking and Insurance sector, however, was also nationalized.) Truitt (1970) finds that expropriation of British and American firms throughout the 1945-1970 period was most common in the petroleum industry.

There are several common explanations in the literature for why resources (and to some extent also utilities) are more prone to being expropriated. One category of explanations emphasizes technological considerations. First, it may be that technologies used in these industries tend to be relatively easy to manage or operate, or require few specialized inputs from parent companies, and as a result the effective return to expropriated capital may be high in these industries in comparison to other industries. The importance of firm-specific knowledge in deterring expropriation is explored in Eaton \& Gersovitz (1984) and Raff (1992), and evidence that expropriation is deterred in industries where managerial and technical knowledge play a crucial role is found in Kobrin's (1980) comparison of different manufacturing industries.

Other technological considerations are the prevalence of sunk costs in resources, combined with mineral price volatility (Nellor, 1987; Monaldi, 2001; Engel \& Fischer, 2010), and varying uncertainty over project returns at various phases of investment (Kobrin, 1980). Mineral extraction typically requires large outlays for exploration and excavation infrastructure before any revenues are realized. Furthermore, project returns are highly uncertain at the exploration and even mine development stages. These features of mineral extraction imply that investors are particularly exposed to the familiar obsolescing bargaining proposed by Vernon (1971). Whereas multinational investors are able to secure relatively favorable contracts terms when the quality of mineral deposits is uncertain, the bargaining power shifts to the host country government once profitability is known and the large sunk investments become hostage. The problem may be more severe when the mineral price is more variable since an agreement that offers the host country a satisfactory share of total rents when the mineral price is relatively low can suddenly be perceived as too generous towards investors when the price is high.

The other category of explanations for the vulnerability of resource extraction to expropriation emphasizes the political sensitivity of foreign ownership in these industries. Some have pointed to the relative importance of extractive industries, as well as utilities, rail, communications and national defence, to political and economic independence and national security. ${ }^{32}$ It is argued that while some FDI may be desirable in these sectors, there is a tendency to prefer domestic ownership and control. This story is also tied to the rise in expropriations in the mining, utilities, and banking sectors in the 1960s. For instance, Rood (1976) suggests that, a short time after the independence of many former colonial states, foreign control in extractive industries was associated with the perception of foreign dependency, and regaining national control symbolized the removal of this dependency. Kobrin (1980) and Kennedy Jr. (1993) additionally conclude that, in many cases, foreign ownership had been most concentrated in mining and

\footnotetext{
${ }^{32}$ See Kobrin (1980, 1984), Shafer (2009) and Kennedy Jr. (1993) for explanations along these lines.
} 
petroleum, reinforcing concerns over foreign dependency in these sectors. If concerns over national security and independence remain important in accounting for expropriation patterns in subsequent decades, however, they do not explain why expropriating countries have continued to allow foreign investments to reach politically sensitive levels.

A second explanation in the literature that emphasizes tensions arising from a high share of FDI in extractive industries is the "scapegoat hypothesis." This account posits that certain political pressures on host-country governments to expropriate FDI tend to develop when poor overall economic performance coincides with a period of prosperity in industries dominated by foreign-owned firms. Kobrin (1984) proposes that the early years of independence were associated with heightened economic aspirations which, when contrasted with a meager realization of such developmental goals, led to increased frustration and a tendency to blame foreign investors for these failures. Jones Jr (1984) gives a similar account for the timing of Venezuela's petroleum sector expropriations. Knudsen (1974) finds empirical support for this hypothesis in his analysis of 21 Latin American countries during the 1960s, ${ }^{33}$ and Jodice (1980) provides broad cross-sectional evidence of a negative relationship between economic performance and expropriation of FDI in mining and petroleum.

These accounts for the relative vulnerability of mining and petroleum FDI to expropriation, which link political sensitivity of these industries to a threshold level of FDI, suggest a positive relationship between resource-based FDI and a country's propensity to expropriate. They also suggest that expropriation in extractive industries should occur over long cycles, at least at the country level, following periods of considerable foreign investment inflows. However, the aforementioned technological reasons for relatively high risk in extractive industries do not have clear implications for the relationship between resource-based FDI and expropriation. All else equal, if a country's geology has given way to large and profitable mining or petroleum sectors, one would expect the country to have larger FDI stocks in these relatively high-risk sectors, increasing the likelihood of expropriation. However, countries that are characterized by a high degree of political risk or that have a record of expropriating will have difficulty attracting large amounts of FDI in these sectors.

All accounts for the relatively large number of expropriations in mining and petroleum, and in particular those that emphasize differences in production technology, imply that expropriation is more likely when mineral prices are high. Evidence for this relationship is considered below.

Long cycles of resource-based FDI and expropriation are evident in some countries. Bolivia, for instance, nationalized foreign oil in 1937 and in 1969 before targeting the sector again in 2006. Venezuela nationalized the petroleum sector in 1976, bringing the assets of Exxon, Shell, and Gulf under a state monopoly. During the 1992-1997 privatization, many foreign companies (including Exxon) reinvested,

\footnotetext{
${ }^{33}$ Knudsen finds that differences between aspirations (measured by literacy, urbanization, media, unionization, natural resource abundance) and realized welfare (identified by availability of hospitals and water, per capita incomes, investment and growth rates, and infant mortality) are associated with a higher probability expropriation. Because natural resource based industries in Latin American countries had contained large amounts of FDI, the estimated relationship is interpreted as evidence of heightened frustration and dissatisfaction with foreign investment relationships during this period. Gurr (1971, p.13) explores a similar idea in explaining large-scale political upheaval, which he refers to as relative deprivation.
} 
Table 4: Sector FDI and Output: Expropriators vs Non-Expropriators

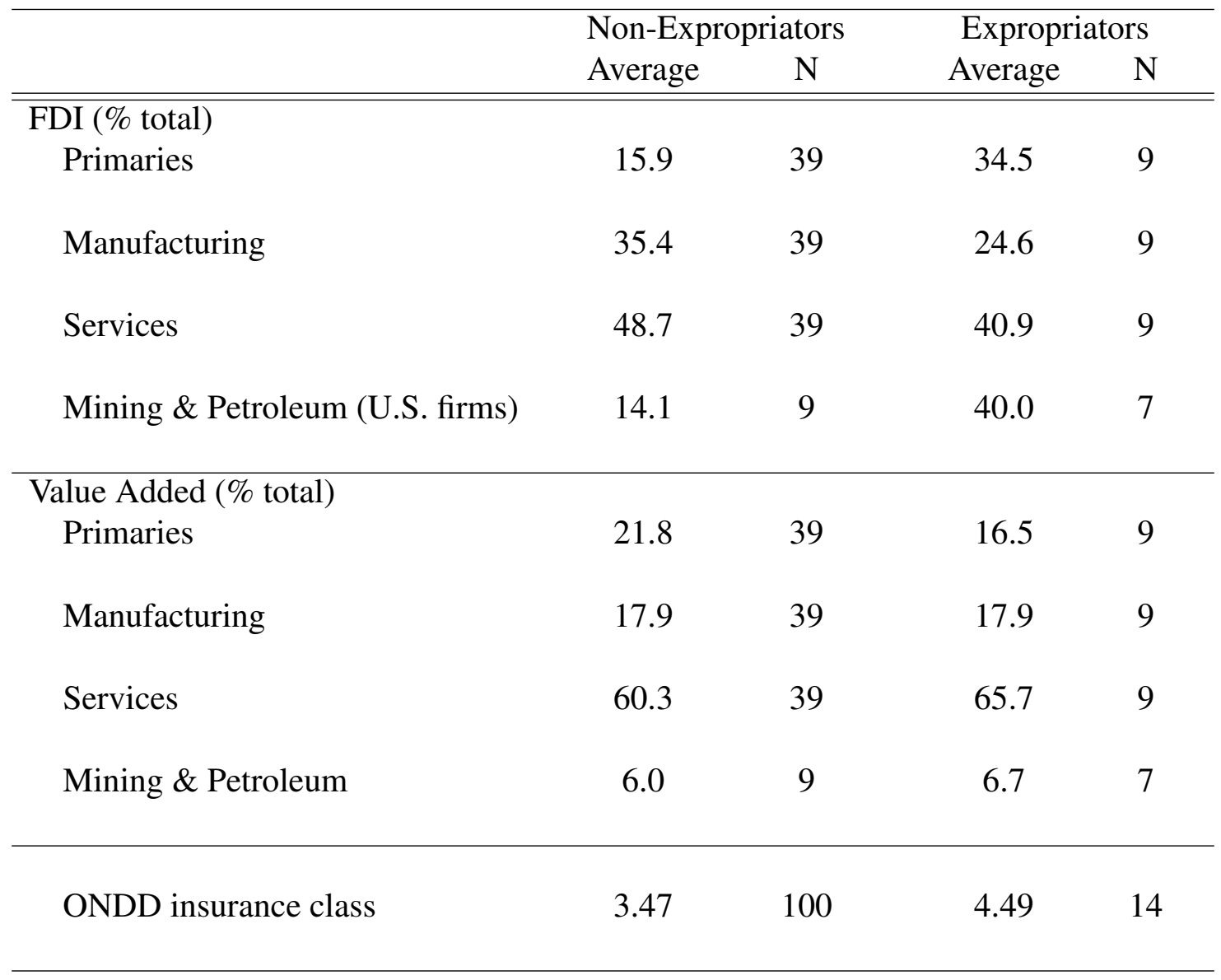

but have had their assets seized by the state again in $2006 .{ }^{34}$ Ecuador, Iran, and Yemen have also nationalized the petroleum sector multiple times, and several examples can be found in mining. This highlights a certain willingness of foreign investors in mining and petroleum to invest despite the higher risks of expropriation in these sectors. This willingness to invest in resources in countries that are likely to expropriate is also evident when examining sectoral patterns of FDI across countries.

The relationship between FDI and country risk has not been examined at the sector level for a large sample of countries. In Table 4, we compare the sectoral distribution of FDI stocks in countries that have expropriated and countries that have not expropriated during the 1993-2006 period. The sector FDI figures represent average 1997-2001 stock values. ${ }^{35}$ Expropriating countries have a higher average share of aggregate FDI located in resources. The average primaries share of FDI in expropriating countries

\footnotetext{
${ }^{34}$ During the mid 1990s, Venezuela was top on the list for foreign investment in petroleum exploration and production.

${ }^{35}$ This represents the period with a maximum number of cross-sectional observations corresponding to sector FDI, and measures stocks roughly in the middle of the period defining expropriators and non-expropriators. For a few countries, the latest available FDI stock estimate is before 1997. For these countries, the 1995-1996 average is used. The reason average shares over the entire 1990-2003 sample period are not considered is that there have been significant time trends in sector FDI shares. Countries for which FDI data is not available at all before 1995 are excluded from the reported averages, but including them does not impact on any of our findings.
} 
is more than double the average for non-expropriating countries. ${ }^{36} \mathrm{FDI}$ in mining and petroleum is also compared across groups using the Bureau of Economic Analysis's estimated outward FDI stocks of U.S. parent companies (FDI in other primaries industries are included in a residual category and cannot be compared), although the number of observations is still quite limited. The difference in FDI shares for these industries is even more pronounced - expropriating country shares are nearly three times those of non-expropriating countries.

This indicates that the distribution of FDI is important in explaining the large number of resourcebased expropriations in total acts. Country differences may reflect an average response of expropriating countries to public frustration arising from high degrees of foreign ownership in politically sensitive industries, or it may be case that geological factors have contributed to relatively large stocks of FDI in the high-risk primaries sector in expropriating countries. A simple test for the latter hypothesis is to examine whether the primaries production shares in expropriating countries tend to be large compared to non-expropriating countries. However, differences in the average primaries output share between expropriating and non-expropriating countries are in fact small, as indicated in Table 4, and if anything work in the opposite direction. Primaries accounts for an average $22 \%$ of total output in the non-expropriating country sample, and only $17 \%$ for expropriating countries. There is also little difference in the average mining and petroleum production share for both groups, although the expropriating country average is slightly larger in this case $(6.0 \%$ and $6.7 \%)$. This suggests that country differences in the degree of resource reliance do not account for the sectoral patterns of FDI and expropriation observed.

Whether the relatively high expropriation risk in resources is associated with heightened political sensitivity over foreign ownership in this sector or the result of technological differences that make FDI in resources more vulnerable to the opportunistic motives of governments, there is a challenge in explaining why this sector is a relatively attractive destination for FDI in expropriating countries, especially if the perceived risk in these countries is relatively high. The final row in Table 4 indicates that expropriating countries tend to be classified under higher expropriation-insurance risk categories. ${ }^{37}$ Such risk ratings could be informed by the concentration of FDI in certain industries as well as by a recent expropriation act, and therefore they should not be taken to be an exogenous country risk measure. Nevertheless, explaining why seemingly high-risk countries attract a larger proportion of their FDI to industries that are expropriated relatively often requires a somewhat different perspective than those already proposed. ${ }^{38}$

\footnotetext{
${ }^{36}$ Although the sample is small, the difference in primaries FDI shares between groups is significant at the $5 \%$ level using a two-tailed test. Only nine of the 24 expropriating countries form a balanced sample when combining estimated FDI stocks with United Nations data on sector GDP, which are used in the comparisons throughout this section. These countries (and respective primaries FDI stock shares) are Argentina (.249), Bolivia (.422), Dominican Republic (.001), Ecuador (.671), Indonesia (.560), Kazakhstan (.604), Mexico (.020), Russia (.163) and Venezuela (.405). For U.S. FDI in mining and petroleum shares, there are only seven expropriating countries in the balanced sample: Argentina (.028), Ecuador (.544), Egypt (.64), Indonesia (.783), Mexico (.009), Russia (.448) and Venezuela (.343). However, the averages are very similar when the full, unbalanced samples are used instead.

${ }^{37}$ ONDD risk refers to the risk category listed by the Office National du Ducroire expropriation insurance company. Group averages are based on 2002-2006 country averages, 2002 being the first year for which this insurance has been offered. Higher index values correspond to higher risk categories.

${ }^{38}$ Holburn \& Zelner (2010), in their examination of the relationships between source-country characteristics, risk, and
} 
An explanation for these findings might be that governments in countries with high political risk or instability tend to offset this risk with cheap access to mineral rights. The recent survey by UNCTAD (2000) on tax incentives and foreign investment notes that while developed countries often employ financial incentives such as grants and subsidies, the direct drain on the government budget makes such policies particularly difficult in poor countries. Instead, these countries tend to use fiscal incentives that do not require upfront use of government funds. Indeed, tax incentives such as extended tax holidays or corporate tax reductions are popular schemes adopted by governments hoping to attract more investment. Additional measures include accelerated depreciation allowances, allowing investors to write-off capital outlays at a rate in excess of economic depreciation, low restrictions on profit repatriation and import duty exemptions.

In the case of mineral extraction, manipulation of royalty rates provides an additional incentive mechanism that is not available in other industries. A lowering of or exemption on royalty payments can significantly raise the returns anticipated by investors. Capital write-offs can also significantly raise the returns in this capital intensive sector, particularly following the early exploration phase of the project. In a survey conducted by the IMF Capital Markets Consultative Group (2003) investors indicated that although tax incentives generally cannot substitute for political stability, growth potential, and the availability of infrastructure, they can play an important role in attracting FDI in the extractive sectors where the fixed costs are high and investments are generally front-loaded. Foreign investors operating in Africa additionally reported that they tended to restrict their investments to the extractive industries in higher risk countries because it was here that opportunities in for taking advantage of natural resource availability were sufficient to offset legal problems and political risks.

Although it is difficult to find very broad evidence linking tax and royalty rates and country risk, royalty rates in many developing countries can be remarkably low. ${ }^{39}$ Zimbabwe, Argentina, Peru and Bolivia, for instance, each had copper mining royalties of $1 \%$ or less during the 1999-2003 period (compared to an average of $3 \%$ in a sample of 29 developing countries). Although royalties do not account for all taxes levied, these countries also had some of the lowest effective tax rates for copper mining, ranking $3 \mathrm{rd}$, 4th, 6th and 7th out of 19 developing countries. ${ }^{40}$ In petroleum. Venezuela and Ecuador had rates less than $1 \%$ prior to 2001 . These rates have since been raised substantially to $30 \%$ in Venezuela in 2001

foreign investment in the utilities sector, emphasize the impact of country risk on the source of FDI. Although high country risk is still hypothesized to be a deterrent to foreign investment, multinational investors that are based in countries facing a similarly high degree of political risk are expected to be more willing to invest, and increased FDI from these source countries may significantly offset lower investment originating in countries with high levels of political stability, particularly in high risk sectors such as utilities and resource extraction.

${ }^{39}$ Systematic data on royalty rates for a large cross section of countries and range of minerals is difficult to find and the evidence presented here is based on the data that we have been able to collect pertaining to copper mining.

${ }^{40}$ Data on royalty rates in selected mining industries has been compiled from numerous sources. Primary sources are Otto et al. (2006), Price Waterhouse Coopers (1999), Rivas et al. (2005), and Wahju (2002). Effective tax rates estimates are taken from Otto (2000). Some countries, such as Chile and Mexico, did not have royalty-based taxes at all during this period, and were not included in the sample. Chile instituted a new Mining Tax Code in 2006, which imposed a sliding-scale royalty system for copper with rates ranging from $0.5 \%$ to $5 \%$, depending on the volume of output. In Argentina, rates differ according to province, with a maximum rate of $3 \%$. 
and to $50 \%$ in Ecuador in 2006. This compares to a global average of around 7\%. And while each these countries have had the lowest observed royalty rates in these two sample industries, most of them have also expropriated FDI during the 1993-2006 period. (Peru is the one exception, although Argentina's expropriation did not involve the mining or petroleum sectors.)

The Venezuelan petroleum sector provides a clear example of manipulating royalty rates both as incentives to foreign investors and as a means of expropriating the value of these investments. When oil prices were low in the 1990s and the profitability of oil in the Orinoco belt was still uncertain, the government set a royalty rate of only $1 \%$. Venezuela soon became an attractive destination for FDI in petroleum exploration and extraction and, in 1996, 14 oil companies paid nearly $\$ 250$ million for the rights to explore in eight areas. ${ }^{41}$ As the profitability of these investments became known, the government raised the royalty rate to $16.7 \%$. By 2005 , approximately 500,000 barrels of oil were being produced each day through a total of 32 operating contracts and, as oil prices continued to rise, royalties were hiked to $30 \%$. Moreover, the government ordered foreign oil companies to set up joint ventures controlled by the state oil company Petroleos de Venezuela (PDVSA). It was in 2006 that the Venezuelan government took control of two mature oilfields operated by Total and Italy's Eni after the two companies failed to agree to form joint ventures in which the PDVSA would hold a majority stake. Other companies reluctantly agreed to form joint ventures. ${ }^{42}$

This anecdotal evidence is merely suggestive of a potential link between tax incentives in extractive industries and political risk. However, it is not obvious under what circumstances giving foreign investors cheap access to minerals would increase FDI in resources or would benefit the host country. If political risk poses a significant barrier to investment, then lowering taxes and royalty rates can potentially raise total revenues through an increase in investment and output. But the resulting reduction in the host country ex post share of project returns could also make foreign firms greater expropriation targets. The increase in risk brought about by lower taxes may therefore limit the capacity to raise FDI by using such incentives.

Relative price movements are also important in explaining expropriation in the primaries sector. Using all of the country and commodity group observations in our 1989-2006 sample of expropriation acts, we check whether large mineral price movements coincide with the timing of expropriation, and find strong evidence for this relationship. Corresponding to each act for which relevant commodity-specific price statistics could be found (including cement), deviations in trend in the year prior to expropriation is considered. A total of 21 acts are examined. ${ }^{43}$ With the exception of the composite agricultural price category, which is taken from the IMF's International Financial Statistics database, all commodity prices are average annual price statistics taken from various issues of the United States Bureau of Mines Min-

\footnotetext{
${ }^{41}$ See "Venezuela, Nationalized No More." Capital Markets Report. 29, July, 1996.

${ }^{42}$ Ecuador and Bolivia have had similar experiences in petroleum, hiking royalty rates to $50 \%$ in 2005 .

${ }^{43}$ Seven acts occurred in petroleum (Bolivia, Ecuador, Turkmenistan, Russia, Yemen, and Venezuela), one act in iron ore (Kazakhstan), five in gold (Democratic Republic of Congo, Kyrgyzstan, Venezuela, and Uzbekistan), two in aluminum (Kazakhstan and Azerbaijan), three in cement manufacturing (Egypt, Sri Lanka, and Venezuela), and three in agriculture (Venezuela and Zimbabwe).
} 
Table 5: Expropriation and Commodity Prices

\begin{tabular}{lcccc}
\hline & $\begin{array}{c}\text { Exprop. when } \\
\text { price is } \\
\text { above trend }\end{array}$ & $\begin{array}{c}\text { Exprop. when price } \\
\text { is } 10 \% \text { or more } \\
\text { above trend }\end{array}$ & $\begin{array}{c}\text { Exprop. when price } \\
\text { is } 10 \% \text { or more } \\
\text { below trend }\end{array}$ & $\begin{array}{c}\text { Total } \\
\text { Obs. }\end{array}$ \\
\hline \hline Number of & 16 & 15 & 3 & 21 \\
Expropriation Acts & & & & \\
\hline
\end{tabular}

Trend price is calculated as the forecasted price based on commodity prices in the 10 years preceding the expropriation year.

erals Yearbook. For each act, a 10-year, linear time trend is used to forecast the price of the commodity in the year prior to expropriation, and we measure the percent deviation in the realized price from this forecasted price. The conjecture is that an opportunistic motive will be reflected in the tendency to expropriate whenever the actual price jumps above trend, or when there is a commodity price "boom". Indeed, this boom may last several years, but provided governments tend to expropriate relatively close to the beginning of the price boom, price deviations based on a 10-year trend should be sufficient to capture this effect.

In 16 of the 21 cases, the average annual commodity price was above trend in the year preceding expropriation (see Table 4.2), with an average deviation of 24\%. In 15 instances, the price deviation was greater than $10 \%$, and in only three cases was the deviation less than $-10 \% .{ }^{44}$

We also document a positive relationship between the frequency of expropriation and resource prices for the broader sample during the 1980-2006 period. ${ }^{45}$ We look at the correlation between the number of expropriation acts in a given year (using a three-year rolling average) and the index for average, developing country commodity export prices published by the IMF's International Financial Statistics to measure resource price fluctuations. We detrend the price index using a Hodrick-Prescott filter. Expropriation tends to be more common when the price index is high, with a correlation coefficient of 0.45 . When only resource-sector expropriations are considered, the correlation coefficient is $0.51 .^{46}$ We view this as fairly compelling evidence that host-country governments are at least partially motivated by the profitability of investments when deciding whether and when to expropriate.

Similar evidence has been documented elsewhere. Duncan (2005) links expropriation to commodity price movements for a sample of 27 countries and seven metallic minerals, and using a broader definition of expropriation than the one employed here. ${ }^{47}$ Guriev et al. (2009) also provide extensive evidence on

\footnotetext{
${ }^{44}$ Ten observations represented positive price deviations greater than $20 \%$, with no negative price deviations in excess of $10 \%$. The same exercise was also done using a 20 -year time trend, with no difference in these results.

${ }^{45}$ The 1960-1979 period is omitted from this analysis since a large proportion of expropriations during this period appear to be driven by the timing of colonial independence, as discussed in Section 4.1. As a result, the correlation with commodity prices over this period is, if anything, negative.

${ }^{46}$ The penalty parameter is 3200 . The correlation coefficient is not highly sensitive to this choice.

${ }^{47}$ The minerals examined are bauxite, copper, lead, nickel, silver, tin and zinc. The 27 countries in the sample are based on the eight largest developing country exporters for the period 1965-1975 for each of these minerals. The definition of expropriation in this data set is very similar to an act, except that a rise in taxes not agreed upon as part of the original contract is considered an expropriation regardless of whether divestment of any portion of company assets occurs or not. Duncan
} 
petroleum sector expropriations and oil prices over the $1960-2003$ period. $^{48}$

That the timing of expropriation in extractive industries coincides with high anticipated returns is consistent with several of the hypotheses reviewed above. In countries where foreign ownership is high in these industries, periods of high ex post rents are more likely to be perceived as unfair and possibly even as being at the expense of development goals in other sectors. The opportunistic expropriation incentive of governments seeking to maximize either host-country welfare or government revenues is also greater when these returns are high. This is in line with the standard assumptions of many formal models of expropriation. (See, for instance, Eaton \& Gersovitz, 1984; Cole \& English, 1991; Thomas \& Worrall, 1994; Tomz \& Wright, 2010.)

\section{Conclusions}

Our analysis of dynamic and sectoral patterns of expropriation and foreign investment in developing countries over the 1960-2006 period establishes a number of stylized facts that have been documented in several empirical investigations that have focused on a more narrow set countries and time periods, as well as several facts related to expropriation in specific industries. Specifically, we have found that the main facts related to expropriation over the 1960-1992 period are largely supported by data for more recent years. Updating Kobrin's (1980) developing country expropriation data set to include the 19932006 period and find that (i) expropriation of FDI continues to be less common since 1980, and appears unlikely to attain the peak levels observed during the 1970s; (ii) natural resource-based FDI is more prone to expropriation compared to other industries, and this difference in risk is stable over time, and; (iii) the timing of resource sector expropriations coincides with positive changes in the value of assets seized.

A number of host-country characteristics, in conjunction with industry-specific factors, give insight into the sectoral and time patterns of expropriation. We find that recent trends are supported by several common explanations given in the literature, but we also provide evidence for a more nuanced interpretation of sectoral expropriation and investment patterns.

Kobrin (1984) hypothesized that the large wave of expropriations in the 1960s and early 1970s appears to mark a unique historical event perpetrated by the political climate in several newly independent countries and the desire to affirm national sovereignty, particularly in industries that are important to national security. In line with this hypothesis, average expropriation levels have remained comparatively low since the mid 1980s. Membership in multilateral investment treaties such as MIGA and the ICSID has likely played a minor role in reducing expropriation incentives, and the absence of any documented expropriation during the mid-1980s appears to be due to a near complete nationalization of foreign assets in vulnerable industries. Moreover, the timing of recent expropriations in mining and petroleum coincides with above-average commodity prices. Mikesell (1984) and others have proposed that increased

gathers data on government taxation activity from the US Bureau of Mines Minerals Yearbook.

${ }^{48}$ This relationship is also suggested in Picht \& Stüven (1991), who find that changes in a country's terms of trade tend to raise the likelihood it expropriates foreign investments. 
adoption of mining and petroleum contracts that allow for greater profit-sharing between host country governments and foreign investors have reduced incentives to expropriate in many countries. Innovations in mining contracts have not insulated all resource-based FDI from expropriation in high-profit states, and have not produced significant reductions in the relative risk of resource-based FDI compared to other sectors. One potential reason for this is that many countries still rely mainly on standard royalties as a source of revenues and make only limited use of more complex profit-sharing contracts. The overall impact of these mining and petroleum contracts on expropriation risk in countries that have used them to a considerable degree is unclear, and is a valuable area for future research.

Although many of the hypothesized reasons for the disproportionate share of resource-sector expropriations have implications for the relationship between country risk and sectoral patterns of foreign investment, this relationship had not been previously examined for a broad sample of countries. We estimate the sectoral distributions of FDI stocks and compare sector shares in countries in expropriating and non-expropriating countries for the 1993-2006 period. Countries that have expropriated since 1993 have relatively large shares of FDI in extractive industries compared to other sectors even though they are not, on average, especially resource dependent relative to non-expropriating countries. From those perspectives that emphasize technological reasons for the relatively high risk in extractive industries, this is not what we would expect if the expropriating country group is perceived as more likely to expropriate. These findings may nevertheless highlight a propensity for heightened public dissatisfaction and mistrust towards foreign ownership when (i) there is a high concentration of foreign-owned firms in these politically sensitive industries, and (ii) the profitability in these industries is high relative to economic performance in other sectors. This raises the question of why investors are relatively more willing to invest in resources when country risk is high. Our conjecture is that governments in countries that are politically unstable and which might be considered relatively risky from a foreign investor's point of view are compelled to offer particularly favorable mineral concessions in order to attract investment. If developing country governments are often constrained in terms of the upfront subsidies and the extent of income tax breaks they can promise to foreign investors, low royalty rates can provide governments with an additional incentive in mining and petroleum over and above those available in other industries. Limited data on country royalty rates in mining and petroleum as well as investor surveys indicate that this has been key factor for attracting FDI for at least some countries.

\section{Acknowledgements}

I thank my advisors James MacGee and Igor Livshits for their invaluable guidance, as well as Hiro Kasahara for several insightful discussions. I also thank Dorian Owen, John Whalley, participants of Small Open Economies in a Globalized World conference (2008), the Canadian Economics Association meetings (2008), the University of Otago, and the Money/Macro seminar at the University of Western Ontario for helpful comments. I am also grateful to Stephen Kobrin for providing his original data. All 
errors are mine.

\section{Appendices}

\section{A Data Appendix}

\section{A.A Expropriation Data: 1990-2006}

Following Kobrin (1980, 1984), data on developing country expropriations are compiled from reports of expropriations published in a wide range of periodicals. Each record of expropriation refers to an expropriation act, which is defined in Section ??. (See text and, in particular, Kobrin, 1980 for a detailed justification for this choice of measure.) Primary sources of data used are:

1. Library of Congress (Fed Research Division)

2. US Dept of State (Invest. Climate and International Claims)

3. The Economist

4. Economist Intelligence Unit

5. Factiva Periodical Database: Globe and Mail, Guardian, LA Times, New York Times, Washington Post, ...

6. ABI/Inform Database: African Reporter, Asia Pacific Business Review, Wall Street Journal, ...

7. International Center for Settlement of Investment Disputes (ICSID): electronically published arbitration claims.

Each database is scanned for any mention of expropriation and other key terms related to expropriation (such as nationalization, indenization, seizure, forced takings, contract repudiation). This search was done country by country for each developing and transition economy as defined by the World Bank.

Whenever a potential expropriation act is identified from a particular source, further internet and periodical searches are conducted to check this case against the criteria for an act defined by Kobrin. Typically this will involve (i) verifying that partial or full divestment of the investor assets occurred, including cases where the company would terminate operations in the host-country, and (ii) that the investment counts as FDI according to the $10 \%$ ownership criteria. (Construction contracts with foreignowned companies are also counted as direct investments if the projects were scheduled to last for more than one year.) 


\section{A.B Sector Stocks of FDI: 1970-2003}

This section details the methodology used to convert available sectoral FDI inflow data into constant US (and PPP) dollar perpetual inventory stock estimates. Primary data sources used are:

- UNCTAD online database (FDI Country Profiles)

- United Nations World Investment Directory (WID): various issues

- Source OECD online database

- Dunning \& Cantwell (1987) (IRM Directory)

Sector FDI stocks are computed by cumulating constant (and PPP) dollar flows with allowances for depreciation. For most OECD countries and many non-OECD countries, book or market value estimates are available and are used to approximate initial stocks when available. (In the case of Paraguay, the most recent stock value and earliest flow data are separated by one or two years, and the most recent stock data are used). For other countries where only cumulative (current dollar) flow data are available (what is often referred to as "historical cost" values), the earliest reported value is taken to be the initial stock, and annual current dollar flows are imputed for the remaining years. In cases where only flow data are available, we follow the standard practice in the sources cited for calculating historical cost initial stock estimates, cumulating flows over the first 5 years of available flow data (after converting flows to constant dollars). In cases where there is strong evidence of little or no FDI prior to the reporting year, due to a change in political regime for example, initial stocks are taken to be inflows for that year (as is done for Ethiopia and initial 1992 stocks). In other cases, where there is evidence of substantial investments in the past, flows are cumulated over a longer 10-year period to obtain initial stocks.

A drawback of the perpetual inventory method (henceforth PIM) for constructing national accounts is that it requires continuous flow series. For many countries, FDI inflows are not available for all years. However, I attempt to correct for the following 4 cases of missing flow data:

1. Stock data reported in the UN's WID are often based on cumulated "current cost" flows. If a continuous series is available, the necessary flow series is implied. If one or more years are missing in the middle of the reported series, however, only the sum of all investments over this period can be uncovered. In constructing the adjusted stock series, this sum is converted at the average exchange rate and price index prevailing over the summation period (i.e. equal investments are assumed to have occurred over the missing-data period). However, if the data gap in question is very large (in excess of 5 years), there is little gain in estimating a continuous series, and instead the reported current cost stocks immediately following the break in the data are taken to be the value of initial stocks. This type of adjustment is made in the case of Argentina (1986-1988, 1991-1992), Brazil (1999), Botswana (1994-1996), and Indonesia (1991,1993). 
2. If sector level flow data are not available for a relatively small interval of time (five years or less) but aggregate flow data are obtained, then sector flows are estimated from period average shares (average over the 2 year periods immediately preceding and following the missing interval) or trend shares (if a strong trend is evident, such as in the case of the Dominican Republic where both primary and manufacturing sector shares are tending to zero before the missing 1991-1994 data period, and are both zero for a number of years following this period). This type of adjustment was made in the cases of Costa Rica (1990-1991), the Dominican Republic (1991-1994), Ecuador (1991), Poland (1990-1993), and Morocco (1991-1992).

3. Finally, cases arise when aggregate flow data are not even available. If no flow data exist for only a small number of years ( 1 or 2 years), then these data are estimated from period averages. This is done in the case of Chile (1991).

4. For a few countries, FDI flow data are not available (or cannot be inferred) at all and are supplemented with data on approved investments (these cases relate to Dominican Republic, Japan, Myanmar, Nepal, and Vietnam). Because not all approved projects are implemented, however, stocks estimated from approved flows will tend to over-estimate actual stocks. Under the assumption that the proportion of approved investments actually carried out in each sector equals the proportion of total approvals implemented, sector stocks are approximated by taking the sector shares from the approved investment series and multiplying these by actual total stock estimates. The estimates of Lane \& Milesi-Ferretti (2007) are used to obtain total, constant-dollar FDI stocks.

In some cases, inconsistencies arise in methods of data collection or reporting methods undertaken by the official reporting agency. In the case of data published by the UN, data are presented as reported. Where possible, efforts are made to correct for these inconsistencies by drawing on supplementary statistics. In the case of Indonesia, investments petroleum exploration are included for 1970-1990 but not thereafter, and we draw on supplementary petroleum investment data published in various issues of 'Petroleum Report Indonesia'. In the case of Canada, there is a change in the industrial classification used during the early nineties (data are reconstructed according to the new classification back to 1981), resulting in a substantive break in the time series. Comparable estimates are constructed for the 1970s using industry level statistics reported in various issues of 'Canada's International Investment Position.' 
With constant dollar FDI flows in hand, sector depreciation rates are then estimated. This is done assuming geometric depreciation rates for each industry/sector from aggregated data: ${ }^{49}$

$$
\delta_{j t}=\frac{D_{j t}}{K_{j, t}}
$$

where $D_{j, t}$ is the total value of depreciation in year $t$ and industry $j$, and $K_{j, t}$ is the gross capital stock. We use Canadian data on depreciated stocks according to industry, published by Statistics Canada, to estimate the geometric rate for each of the 3 sectors over the 1970-2003 period. ${ }^{50}$ Note that variation in this trend across sectors and over time will occur due to changes in the types of assets used. For manufacturing and services, the series are smoothed using a Hodrick-Prescott filter with smoothing parameter 3200 (for primaries the period average is used). Using these annual depreciation rates, sector FDI stocks are calculated as:

$$
F D I A_{j, t}=\left(1-\delta_{j, t}\right) F D I A_{j, t-1}+\frac{F D I_{j, t}}{p_{t}} .
$$

where $F D I A$ measures the stock of FDI assets and FDI measures FDI inflows, measured in constant US dollars.

It is useful to contrast these estimates with the 'book value' FDI stock estimates constructed by Lane \& Milesi-Ferretti (2001, 2007), which are instead intended to capture the replacement cost of investment stocks in 1997 US dollars. This is done by adjusting the stock value of the previous year by changes in a price of capital in the US and changes in CPI relative to the US. ${ }^{51}$ Thus stock values are calculated according to

$$
S F D I_{t}=S F D I_{t-1} \frac{e_{t}^{U S}}{e_{t-1}^{U S}}\left(1+\pi_{t}\right)+F D I_{t}
$$

where $S F D I_{t}$ is the stock of FDI in year $t, e^{U S}$ is the real exchange rate of the country vis-a-vis the US, $\pi$ is the rate of change in the price of capital goods in the US, and $F D I_{t}$ is the recorded inward flow of FDI in year $t$.

\footnotetext{
${ }^{49}$ Standard perpetual inventory capital stock estimates are formed by calculating the average service lives of (i) machinery and equipment (multiple categories), and (ii) buildings and other structures, for each 2-digit ISIC industrial classification, and subtracting the value of retired capital assets from cumulative flows in each year. (Retirements of each type of capital are "smoothed" over time according to an assumed distribution (mortality functions) around their mean service life). Constructing comparable FDI stock statistics is not possible since this would require not only detailed investment data according to type of asset and industry, but also extended time series to incorporate service lives of up to 30 years for machinery and 50 years for structures.

${ }^{50}$ Owing to an estimated decline in the average service lives of various types of equipment and structures since the 1950 s, the geometric depreciation rate implied by these data is gradually increasing over the 1970-2003 period for manufacturing and services. For primaries, the depreciation rate is nearly constant, and the average of 0.058 over the entire period is used. For manufacturing and services, the depreciation rate series is smoothed out using a Hodrick-Prescott filter with smoothing parameter 3200. The smoothed series rise from 0.051 to 0.060 for manufacturing and 0.036 to 0.51 for services. Caselli (2005) uses a constant depreciation rate of 0.06 to estimate aggregate capital stocks for a sample of countries. Alternate estimates are derived using this same depreciation rate for all sectors. Due to the high average growth in FDI over the past 15 years, however, there is little difference in the two estimates.

${ }^{51}$ This reflects the implicit assumption that investment goods are non-traded.
} 
The panels of Figure A.3 display total PIM stocks for 49 countries with estimated stock series extending 5 or more years. These stock estimates are also contrasted with those constructed by Lane and Milesi-Ferretti (the dashed line, denoted LM) as well as the book values or historical cost estimates reported in the original UN or OECD sources where available (represented by the dotted line - in contrasting alternative stock estimates, the constant (1990) US dollar values are used). As can be expected, our PIM stocks are often less variable compared to the LM stocks, which are adjusted according to fluctuations in the country's exchange rate. And while all three series are generally close in magnitude, there are some exceptions. Often these differences point to diverging assumptions concerning initial stock values. This appears to be the case for the Dominican Republic, Ethiopia, India, and perhaps Australia, where in each case the PIM estimates are consistently above or below LM stocks. In other cases there is an evident discrepancy between flow data reported at the aggregate and sector levels, such as in the cases of France, Guatemala, Hungary, Italy, Indonesia, Ireland, and Trinidad and Tobago. For France, Hungary, Italy, and Morocco the discrepancy can, at least in part, be accounted for by the fact that sector flow data do not include reinvested earnings. 
A.3 Sector FDI Stocks (1990 \$ U.S. Millions): Comparison of LM and PIM Estimates
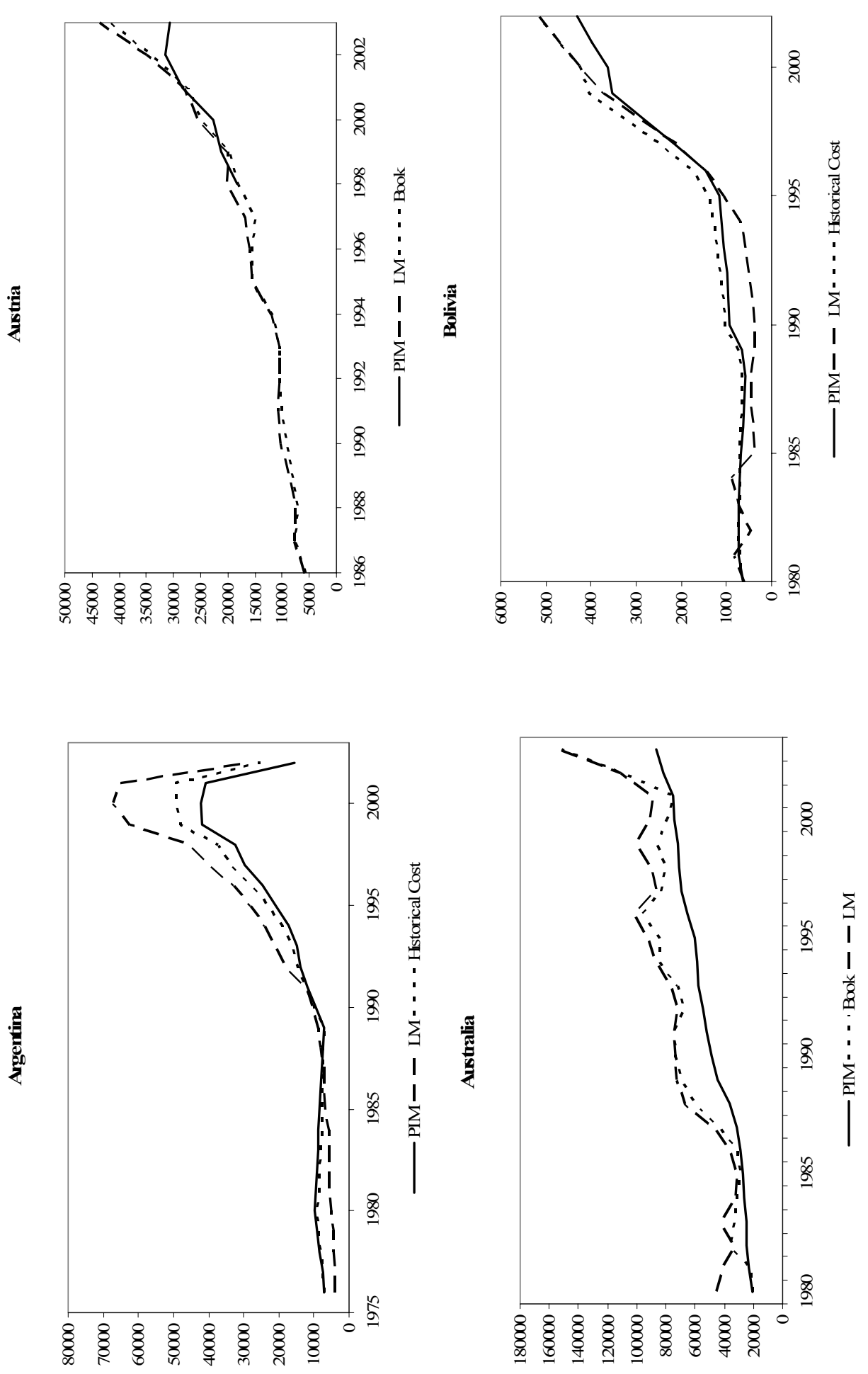

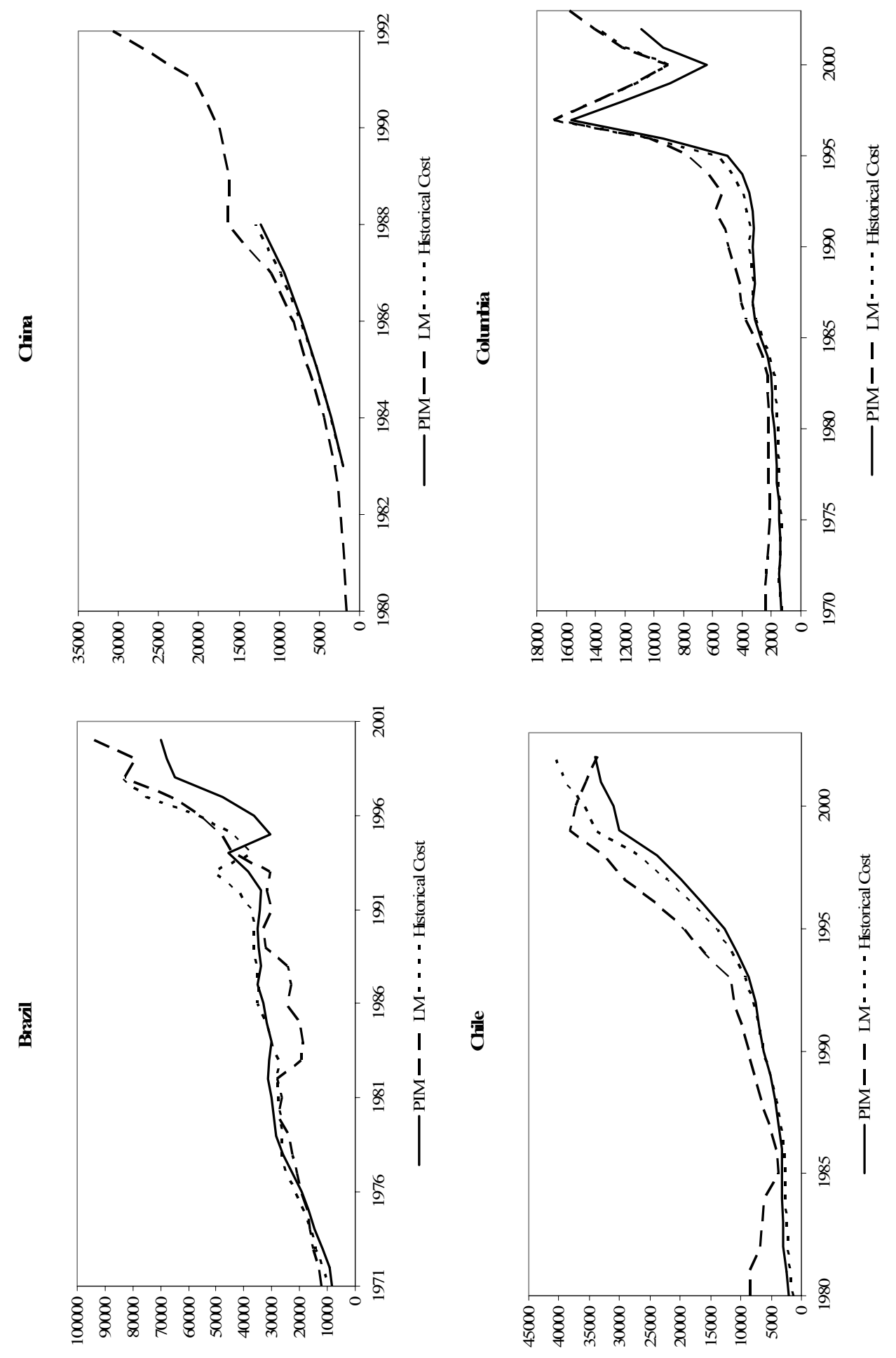

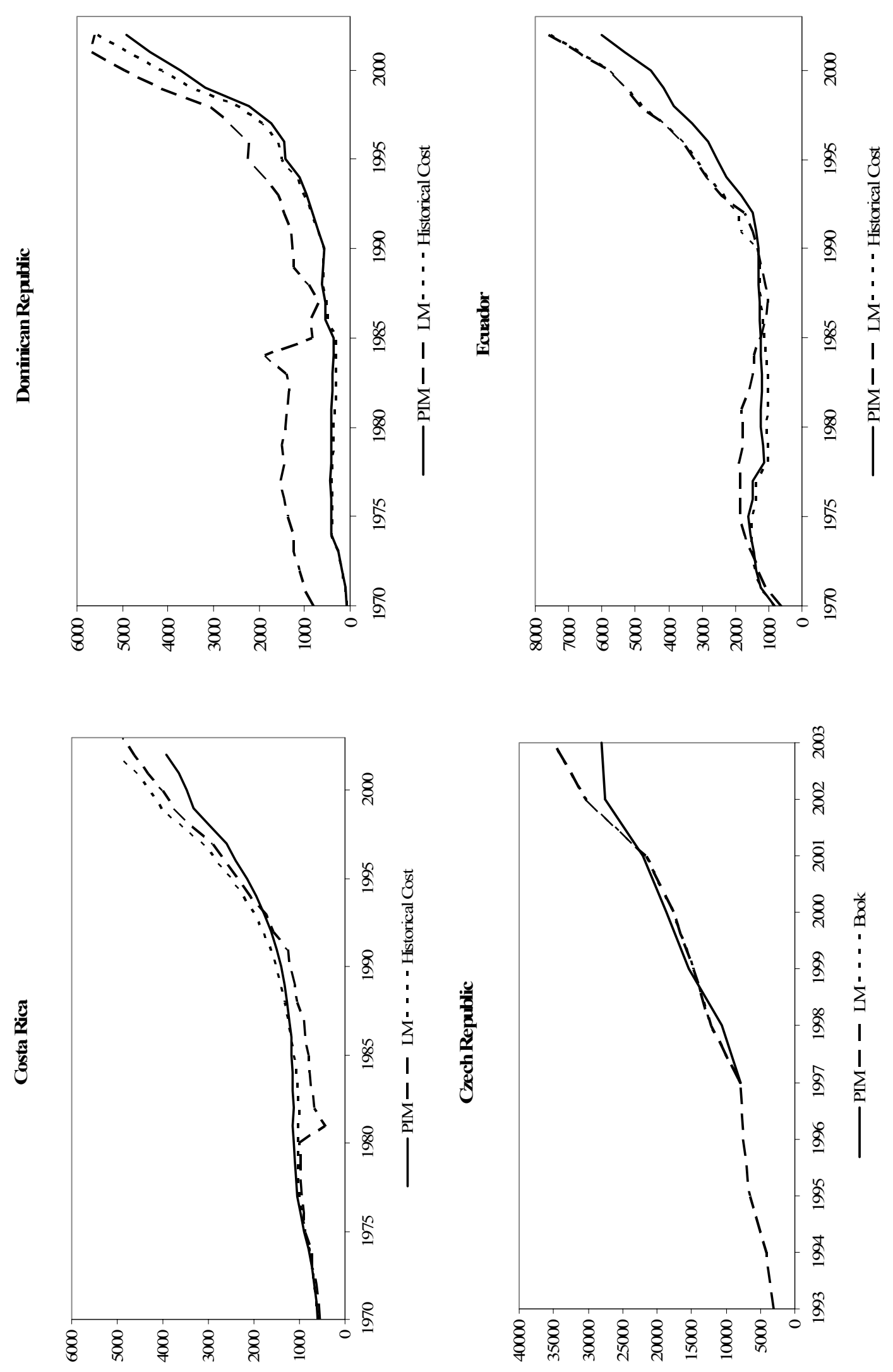

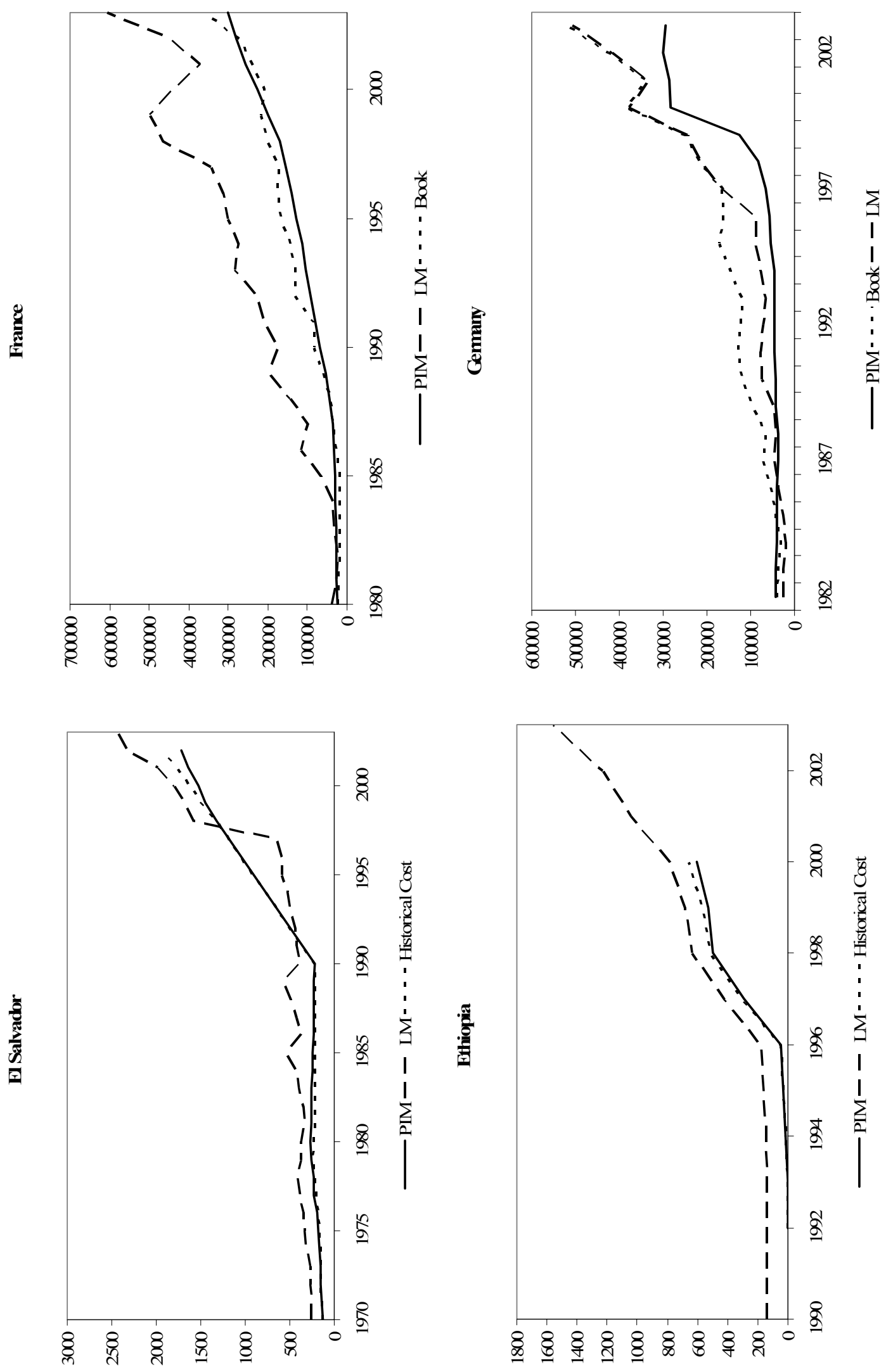

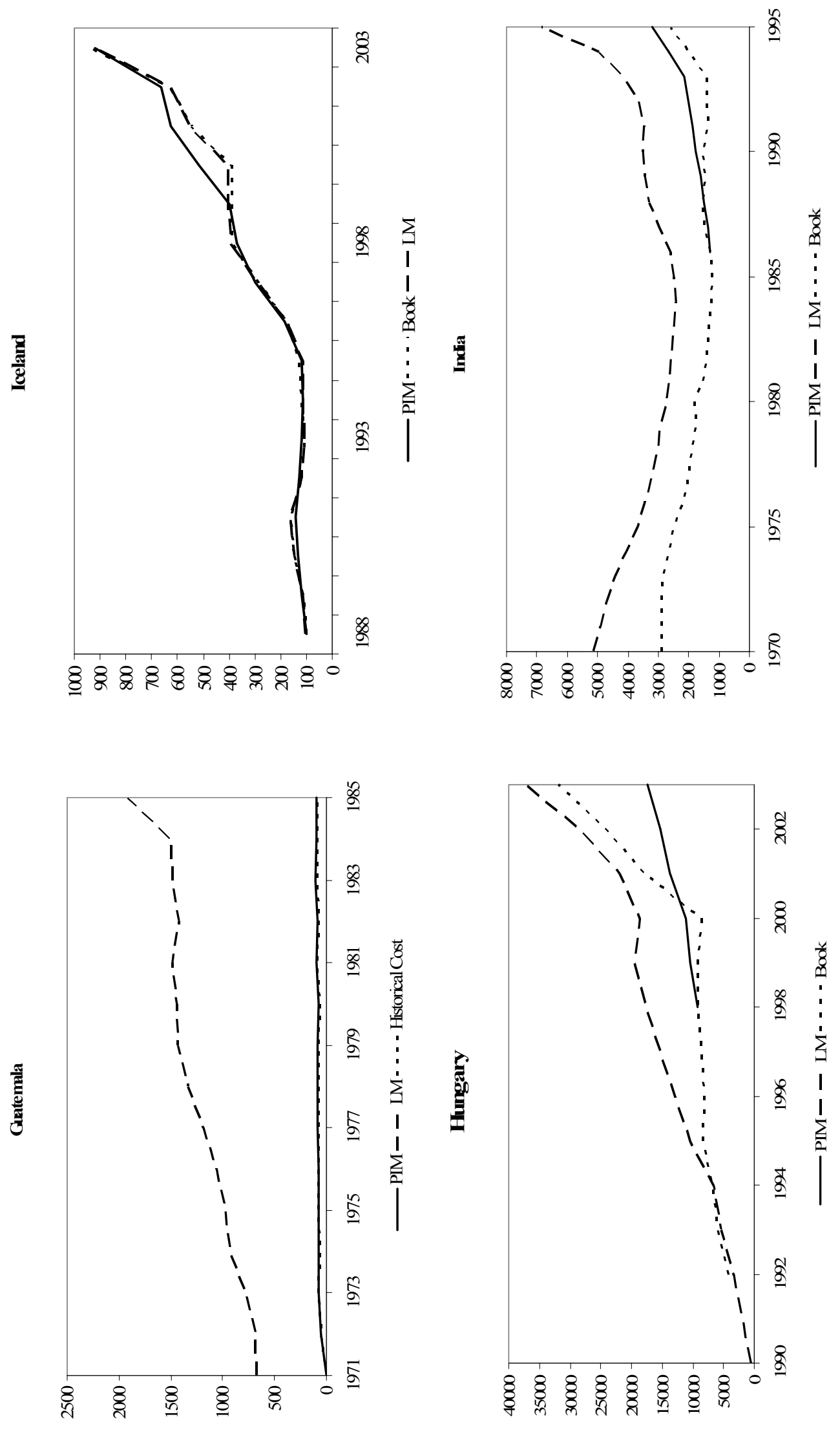

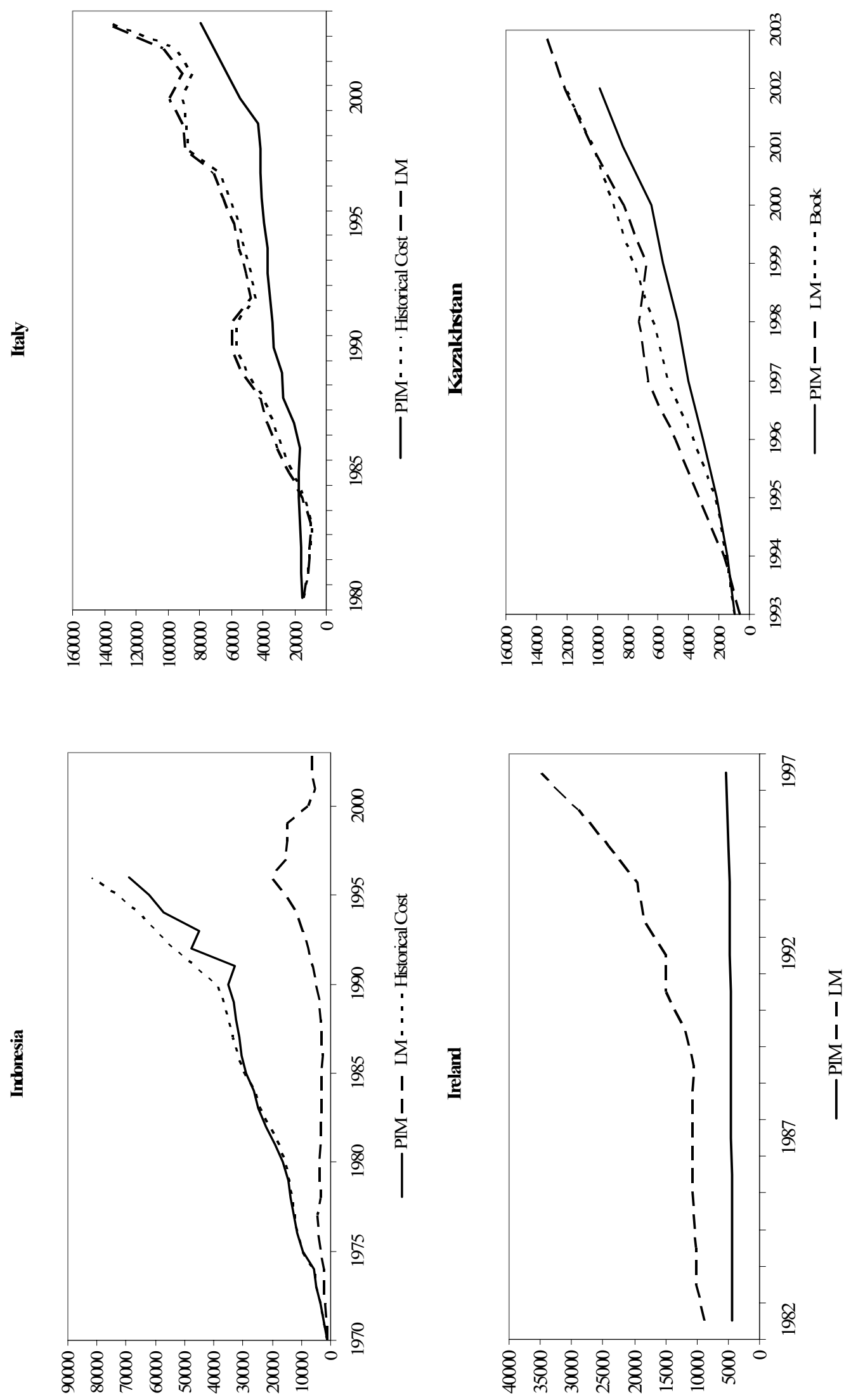

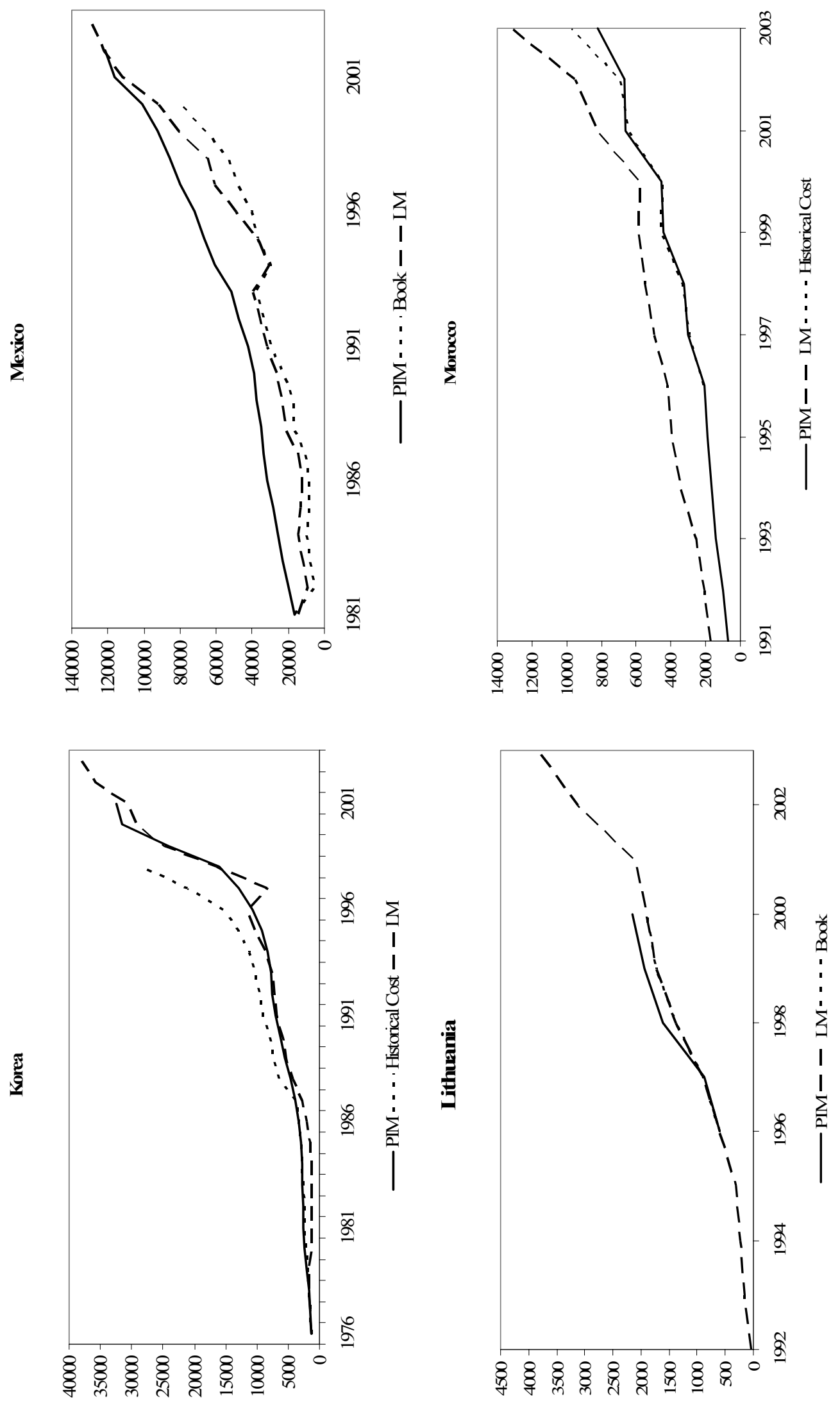

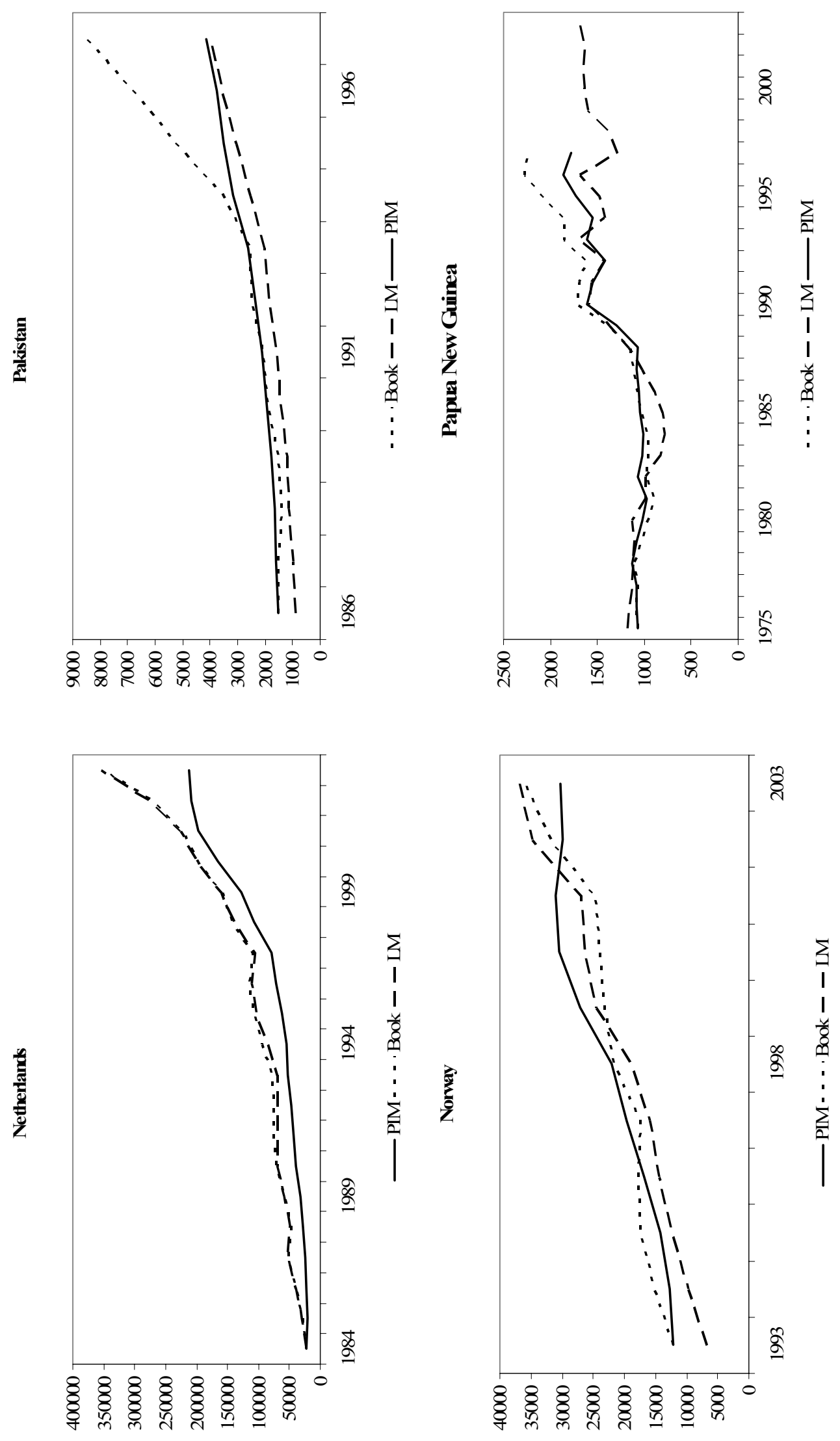

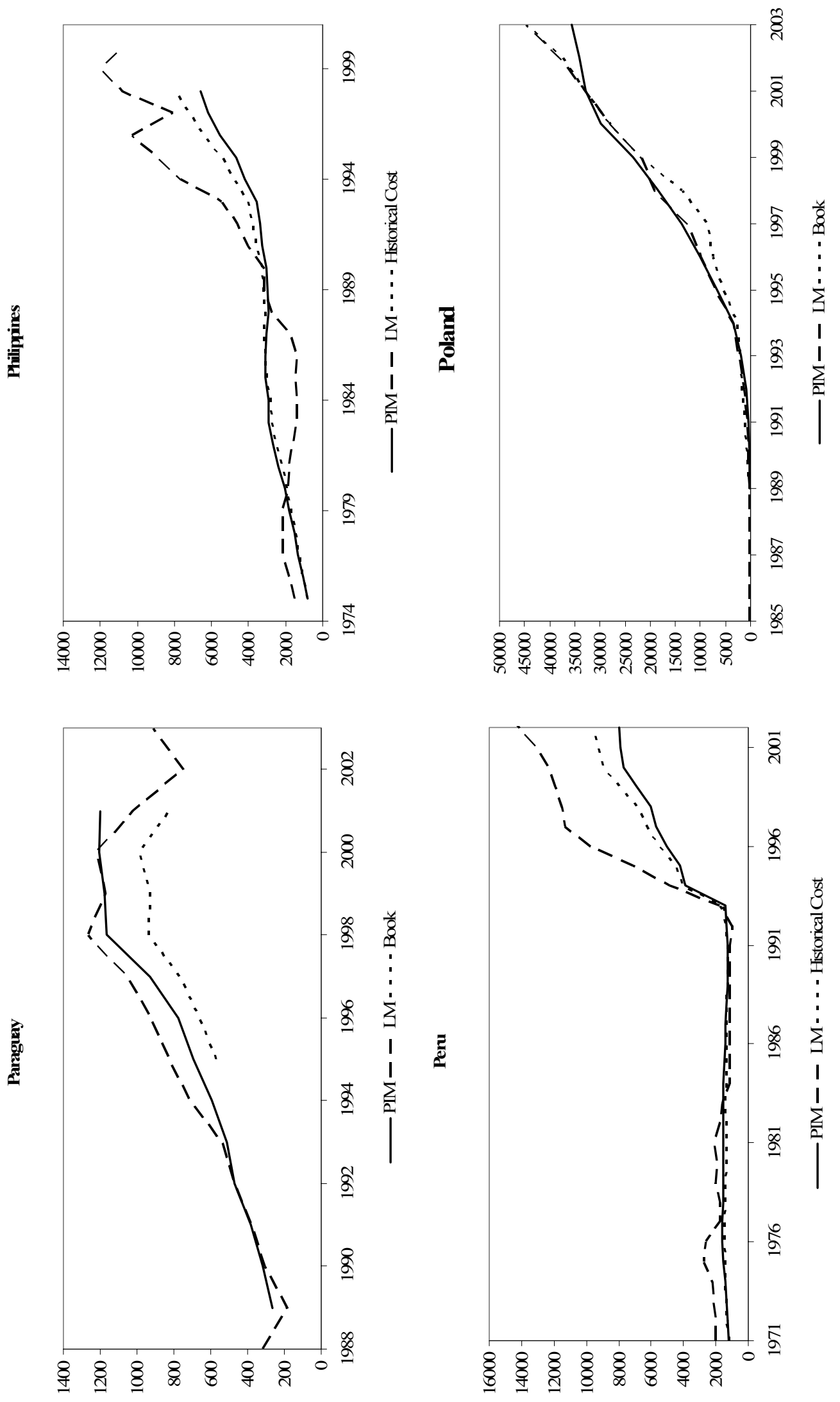

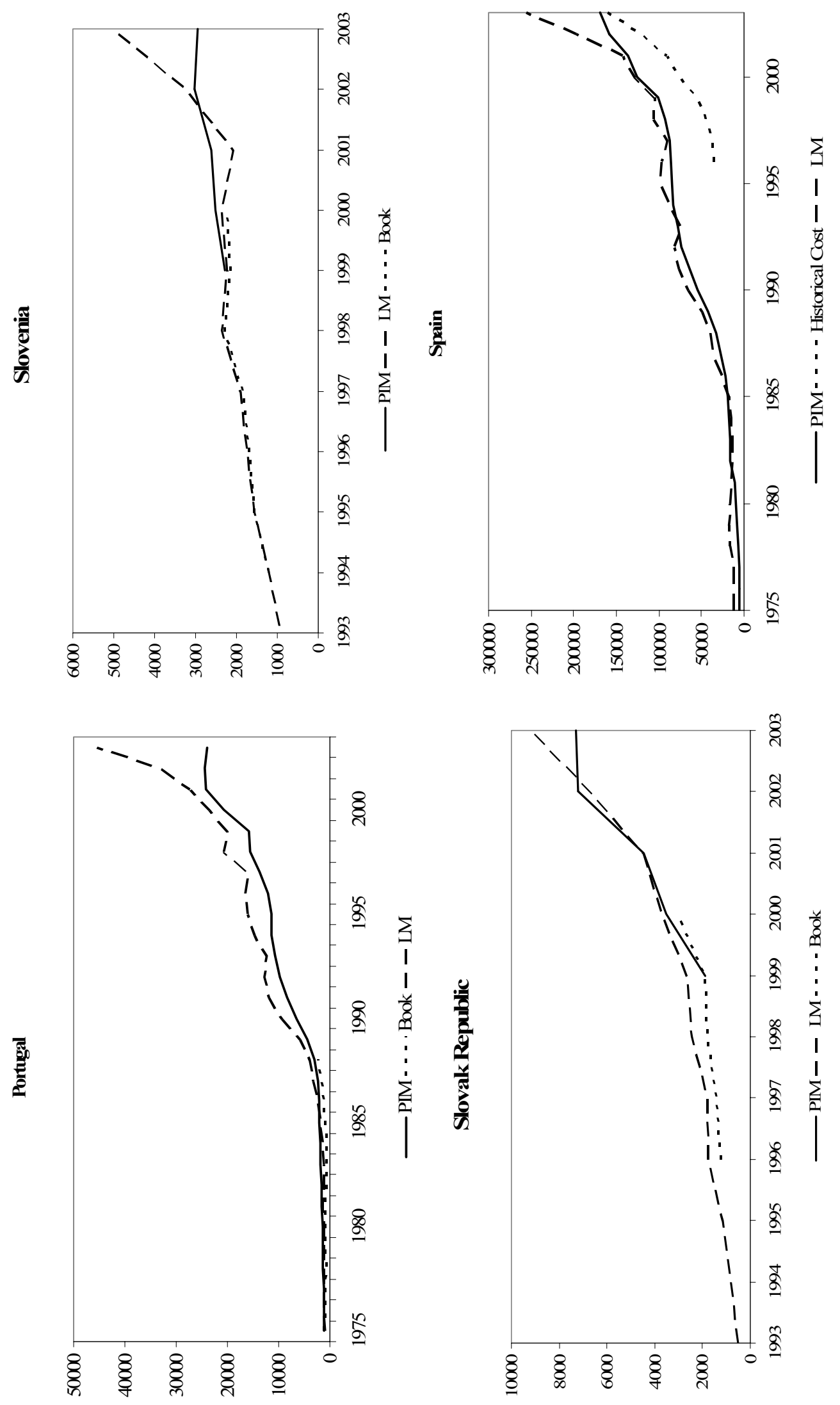

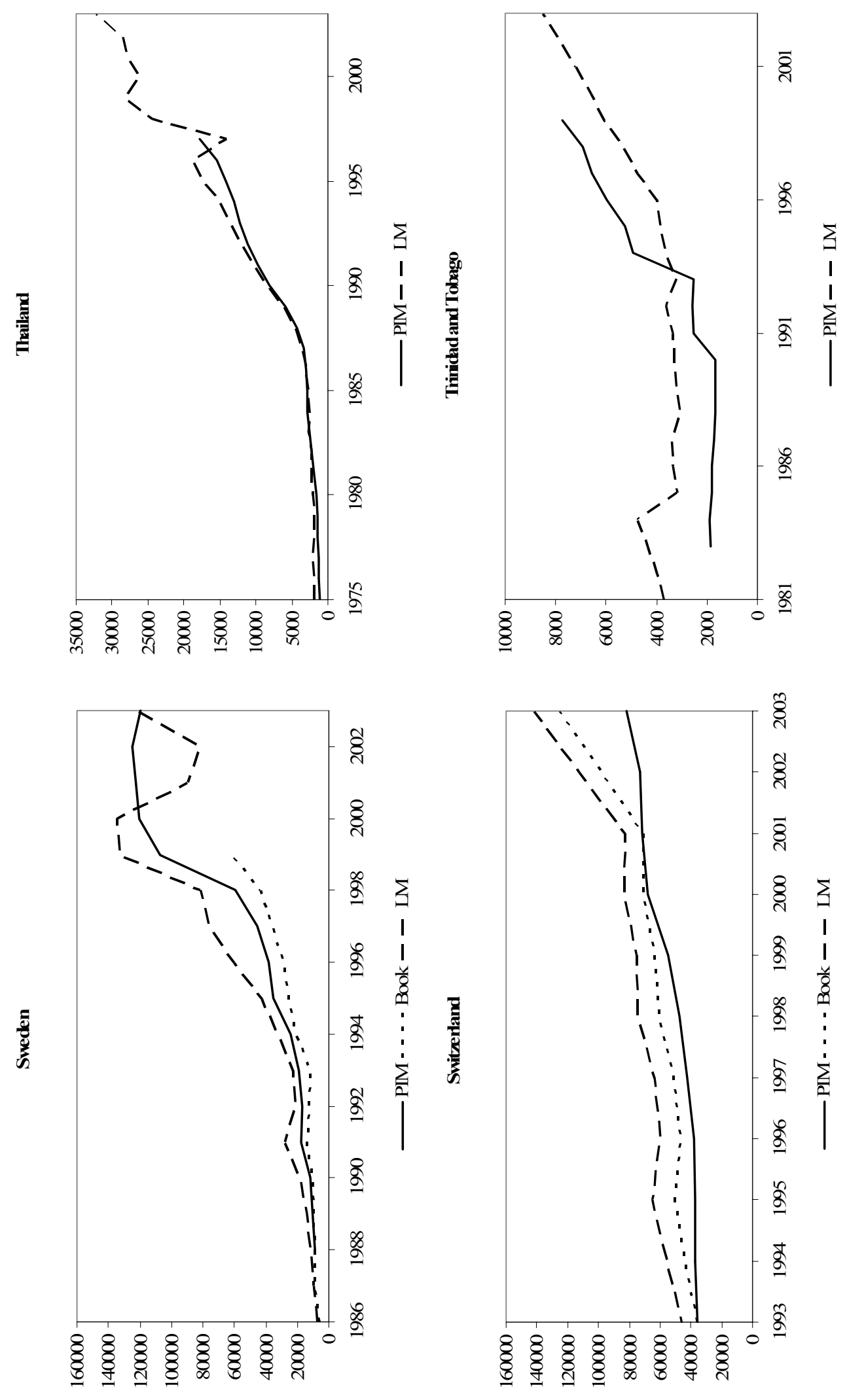

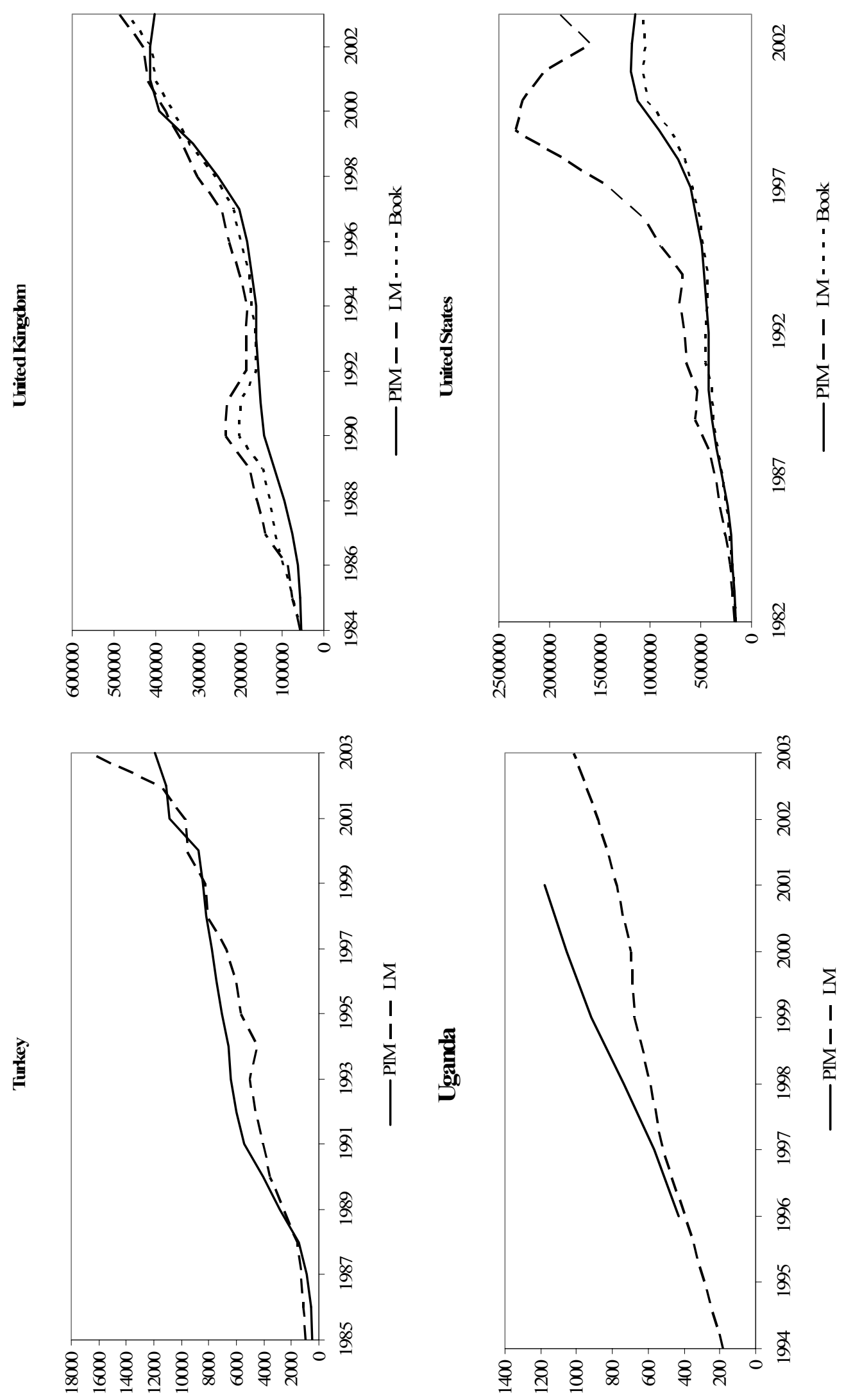


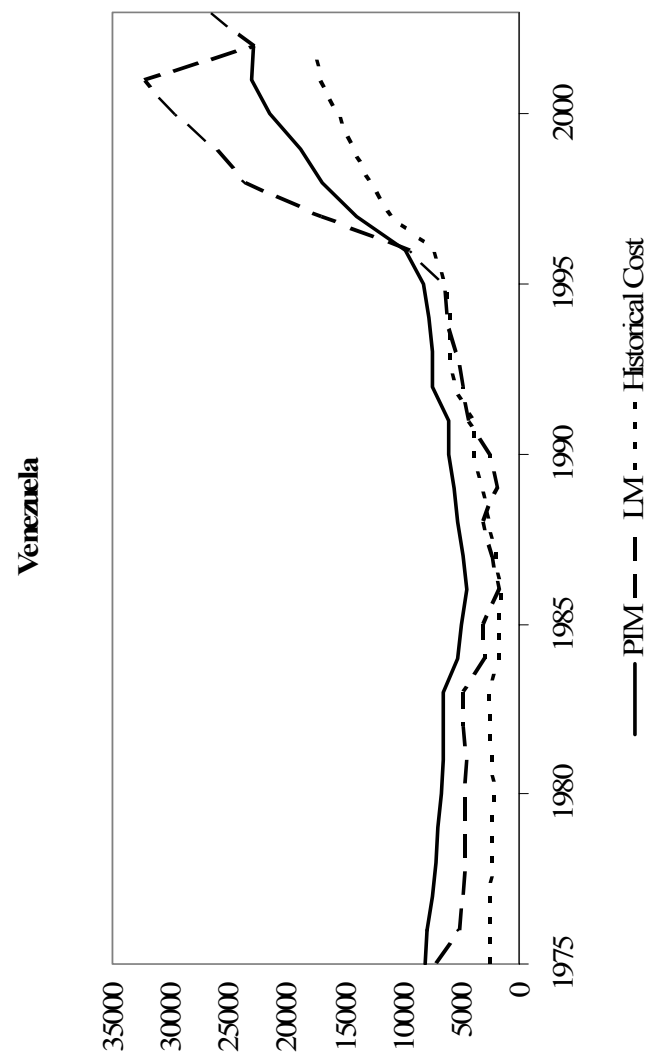




\section{References}

Baunsgaard, T. (2001). A primer on mineral taxation. IMF working paper WP/01/139.

Caselli, F. (2005). Handbook of Economic Growth, chap. Accounting for Cross-Country Income Differences, (pp. 679-741). Elsevier Press.

Cole, H. L., \& English, W. B. (1991). Expropriation and direct investment. Journal of International Economics, 30(3-4), 201-227.

Duncan, R. (2005). Price or politics? an investigation of the causes of expropriation. Australian Journal of Agricultural and Resource Economics, 50(1), 85-101.

Dunning, J., \& Cantwell, J. (1987). IRM directory of statistics of international investment and production. New York University Press.

Eaton, J., \& Gersovitz, M. (1984). A theory of expropriation and deviations from perfect capital mobility. The Economic Journal, 94, 16-40.

Engel, E., \& Fischer, R. D. (2010). The Natural Resources Trap: Private Investment without Public Commitment, chap. Optimal Resource Extraction Contracts under Threat of Expropriation, (pp. 161196). Cambridge, MA: MIT Press.

Gillis, M. (1982). Evolution of Natural Resource Taxation in Developing Countries. Natural Resources Journal, 22, 619-648.

Guriev, S., Kolotilin, A., \& Sonin, K. (2009). Determinants of Nationalization in the Oil Sector: A Theory and Evidence from Panel Data. Journal of Law, Economics, and Organization, (pp. 1-23).

Gurr, T. R. (1971). Why Men Rebel. Princeton University Press.

Holburn, G. L., \& Zelner, B. A. (2010). Political Capabilities, Policy Risk and International Investment Strategy: Evidence from the Global Electric Power Industry. Strategic Management Journal, 31(12), 1290-1315.

IMF Capital Markets Consultative Group (2003). Foreign Direct Investment in Emerging Market Countries. Washington, D.C.: International Monetary Fund.

Jodice, D. A. (1980). Sources of Change in Third World Regimes for Foreign Direct Investment, 19681976. International Organization, 34(2), 177-206.

Jones Jr, R. J. (1984). Empirical Models of Political Risks in US Oil Production Operations in Venezuela. Journal of International Business Studies, 15(1), 81-95. 
Kennedy Jr., C. R. (1993). Multinational Corporations and Expropriation Risk. Multinational Business Review, 1(1), 44-55.

Knudsen, H. (1974). Explaining the National Propensity to Expropriate: An Ecological Approach. Journal of International Business Studies, 5(Spring), 51-89.

Kobrin, S. J. (1980). Foreign Enterprise and Forced Divestment in LDCs. International Organization, 34(1), 65-88.

Kobrin, S. J. (1984). Expropriation as an Attempt to Control Foreign Firms in LDCs: Trends from 1960 to 1979. International Studies Quarterly, 28(3), 329-348.

Lane, P., \& Milesi-Ferretti, G. (2007). The External Wealth of Nations Mark II: Revised and Extended Estimates of Foreign Assets and Liabilities, 1970-2004. Journal of International Economics, 73(2), $223-250$.

Lane, P. R., \& Milesi-Ferretti, G. (2001). The External Wealth of Nations: Measures of Foreign Assets and Liabilities for Industrial and Developing Countries. Journal of international Economics, 55(2), 263-294.

Mikesell, R. F. (1984). Petroleum Company Operations in Developing Countries. Washington D.C.: Resources for the Future.

Minor, M. S. (1994). The Demise of Expropriation as an Instrument of LDC Policy, 1980-1992. Journal of International Business Studies, 25(1), 177-188.

Monaldi, F. (2001). Sunk-costs, Institutions, and Commitment: Foreign Investment in the Venezuelan Oil Industry. Unpublished manuscript, Stanford University, Department of Political Science.

Nellor, D. C. (1987). Sovereignty and Natural Resource Taxation in Developing Countries. Economic Development and Cultural Change, 35(2), 367-392.

Otto, J. A. (1992). Minerals Investment Conditions in Selected Countries of the Asia Pacific Region, chap. A Global Survey of Mineral Company Investment Preferences and Criteria for Assessing Mineral Investment Conditions, (pp. 330-342). New York: United Nations Economic and Social Commission for Asia and the Pacific.

Otto, J. A. (2000). Mining Taxation in Developing Countries. Study prepared for UNCTAD.

Otto, J. A., Craig, A., Cawood, F., Doggett, M., Guj, P., Stermole, F., Stermole, J., \& Tilton, J. (2006). Mining Royalties: A Global Study of their Impact on Investors, Government, and Civil Society. The International Bank for Reconstruction and Development / The World Bank. 
Picht, H., \& Stüven, V. (1991). Expropriation of Foreign Direct Investments: Empirical Evidence and Implications for the Debt Crisis. Public Choice, 69(1), 19-38.

Price Waterhouse Coopers (1999). Asia Pacific Mining Regulations. Washington, D.C.: November Newsletter.

Raff, H. (1992). A Model of Expropriation with Asymmetric Information. Journal of International Economics, 33(3-4), 245-265.

Rivas, R., Renard, S., Vela, D., Rigo, J., Godinez, F., \& Roder, R. (2005). Mining taxation in chile and in the region: A comparative analysis. Tech. rep.

Rood, L. L. (1976). Nationalisation and Indigenisation in Africa. The Journal of Modern African Studies, 14(3), 427-447.

Shafer, M. (2009). Capturing the Mineral Multinationals: Advantage or Disadvantage? International Organization, 37(01), 93-119.

Thomas, J., \& Worrall, T. (1994). Foreign direct Investment and the Risk of Expropriation. The Review of Economic Studies, 61(1), 81-108.

Tomz, M., \& Wright, M. (2010). The Natural Resources Trap: Private Investment without Public Commitment, chap. Sovereign Theft: Theory and Evidence about Sovereign Default and Expropriation, (pp. 69-110). MIT Press.

Truitt, F. J. (1970). Expropriation of Foreign Investment: Summary of the Post World War II Experience of American and British Investors in the Less Developed Countries. Journal of International Business Studies, 1(2), 21-34.

UNCTAD (2000). Tax Incentives and Foreign Direct Investment: A Global Survey. New York: United Nations.

Vernon, R. (1971). Sovereignty at bay: The multinational spread of US enterprises. New York: Basic Books.

Wahju, B. (2002). Indonesian Mining Industry in the Period of Transition, Between 1997-2001. International Convention, Trade Show Investors Exchange, Prospectors and Developers Association of Canada (PDAC), Toronto, (pp. 10-13).

Williams, M. L. (1975). The Extent and Significance of the Nationalization of Foreign-Owned Assets in Developing Countries, 1956-1972. Oxford Economic Papers, 27(2), 260-273. 